\title{
Do biological and management reasons for a short or long dry period induce the same effects on dairy cattle productivity?
}

\author{
K. E. Olagaray, ${ }^{1}$ (1) M. W. Overton, ${ }^{2}$ () and B. J. Bradford ${ }^{1 *}$ (이 \\ ${ }^{1}$ Department of Animal Sciences and Industry, Kansas State University, Manhattan, 66506 \\ ${ }^{2}$ Elanco Animal Health, Greenfield, IN 46140
}

\begin{abstract}
The dry period is a well-established factor that determines lactation success. A retrospective observational study used 32,182 lactations from 16 farms to determine whether management versus biological reasons for deviations from the targeted 60-d dry period have the same associations with subsequent lactation performance. Herd inclusion criteria were Holstein cows, herd size $\geq 900$ cows, breeding by artificial insemination, and (minimally) bimonthly milk testing. Dry period length (DPL) and gestation length (GL) were each categorized as short $[>1$ standard deviation $(\mathrm{SD})$ below mean within herd; means $45 \mathrm{~d}$ DPL, $269 \mathrm{~d}$ GL] or long ( $>1$ SD above mean within herd; means $73 \mathrm{~d}$ DPL, $284 \mathrm{~d}$ GL) and combined to generate the following 7 study groups: short DPL, short GL $\left(\mathrm{S}_{\mathrm{D}} \mathrm{S}_{\mathrm{G}}, \mathrm{n}=2,123\right)$; short DPL, average GL $\left(\mathrm{S}_{\mathrm{D}} \mathrm{A}_{\mathrm{G}}, \mathrm{n}=1,418\right)$; average $\mathrm{DPL}$, short GL $\left(\mathrm{A}_{\mathrm{D}} \mathrm{S}_{\mathrm{G}}, \mathrm{n}=1,759\right)$; average $\mathrm{DPL}$, average GL $\left(\mathrm{A}_{\mathrm{D}} \mathrm{A}_{\mathrm{G}}, \mathrm{n}=19,265\right)$; average DPL, long GL $\left(\mathrm{A}_{\mathrm{D}} \mathrm{L}_{\mathrm{G}}, \mathrm{n}\right.$ $=3,325)$; long DPL, average GL $\left(\mathrm{L}_{\mathrm{D}} \mathrm{A}_{\mathrm{G}}, \mathrm{n}=2,573\right)$; and long DPL, long GL $\left(\mathrm{L}_{\mathrm{D}} \mathrm{L}_{\mathrm{G}}, \mathrm{n}=1,719\right)$. Responses evaluated included milk and component yields at first test and over the whole lactation, days to first service, first service conception risk, days open, and herd retention through 60 and $365 \mathrm{~d}$ postpartum. Continuous data were analyzed by mixed models and time to event data by Cox proportional hazard models, both accounting for clustering at the herd level. First test and whole-lactation milk and component yields were lowest for $\mathrm{S}_{\mathrm{D}} \mathrm{S}_{\mathrm{G}}$. Within cows that experienced calving difficulty, rates of receiving first service were 13 and $20 \%$ less for $\mathrm{S}_{\mathrm{D}} \mathrm{S}_{\mathrm{G}}$ and $\mathrm{A}_{\mathrm{D}} \mathrm{S}_{\mathrm{G}}$ compared with $\mathrm{A}_{\mathrm{D}} \mathrm{A}_{\mathrm{G}}$. Hazard of leaving the herd by $60 \mathrm{~d}$ in milk (DIM) was $34 \%$ greater for $A_{D} S_{G}$ than $A_{D} A_{G}$. Similar effects between $\mathrm{S}_{\mathrm{D}} \mathrm{S}_{\mathrm{G}}$ and $\mathrm{A}_{\mathrm{D}} \mathrm{S}_{\mathrm{G}}$ but not $\mathrm{S}_{\mathrm{D}} \mathrm{A}_{\mathrm{G}}$ indicated that short GL was a greater contributor to poor performance than
\end{abstract}

Received March 2, 2020.

Accepted July 13, 2020.

*Corresponding author: bjbrad@msu.edu
DPL itself. Overall production was similar between $A_{D} A_{G}$ and $S_{D} A_{G}$; however, somatic cell linear score at first test was greater for $S_{D} A_{G}$, and milk yield at first test was lesser for $S_{D} A_{G}$ cows with greater milk at last test before dry-off. Although short DPL might be a successful strategy for some herds or cows, cows with high milk yield at dry-off should not be subjected to a short dry period. Long DPL or GL did not influence early-lactation or whole-lactation milk yield. Cows with a long DPL due to early dry-off $\left(\mathrm{L}_{\mathrm{D}} \mathrm{A}_{\mathrm{G}}\right)$ likely experienced issues related to excessive lipid mobilization, as milk fat concentration and fat:protein ratio at first test were greater and hazard of leaving the herd was 30 and $24 \%$ greater compared with $\mathrm{A}_{\mathrm{D}} \mathrm{A}_{\mathrm{G}}$ by 60 and 365 DIM, respectively. We conclude that deviations in DPL length caused by biology (short GL) were associated with greater effects than management causes of short DPL, whereas management reasons for long DPL were associated with more negative outcomes than long GL. Key words: gestation length, performance, survival, reproduction, dairy cow

\section{INTRODUCTION}

Optimal dry period length (DPL) has been long debated (Annen et al., 2004a). As far back as 1936 and especially from the 1970s to the 1990s, retrospective observational studies conducted to identify optimal DPL (Arnold and Becker, 1936; Schaeffer and Henderson, 1972; Keown and Everett, 1986) generally found negative associations between short dry periods and subsequent milk production. However, nonrandom assignment of cows (Bachman and Schairer, 2003) and failure to account for factors other than DPL in statistical models (Wiggans et al., 2002) created speculation regarding the validity of these results. As Bachman and Schairer (2003) discussed, inherent bias exists in these retrospective study groups because they represent unplanned short or long dry periods. Many of the unplanned short dry periods in these studies were likely the result of various factors that caused cows to calve early (carrying twins, heat stress, or other reasons), 
which are known to decrease cow productivity independent of DPL. Similarly, a large portion of cows with an unplanned long DPL were likely dried off early because of their inability to maintain a minimum level of milk production in late lactation, and this low productivity is likely carried over to the next lactation (i.e., inferior genetics). To account for at least some of the aforementioned bias, Funk et al. (1987) and Makuza and McDaniel (1996) demonstrated the necessity of including previous lactation days open and milk yield when evaluating the effect of DPL on subsequent milk yield; however, even after such adjustments, both provided evidence supporting an optimal DPL between 60 and $69 \mathrm{~d}$.

Production potential of cows has changed considerably over the last 20 years. Such high levels of milk production have resulted in relatively high milk yield at $220 \mathrm{~d}$ of gestation (approximately $24-30 \mathrm{~kg} / \mathrm{d}$; Annen et al., 2004a), leading to concerns about mammary gland health and animal welfare (Zobel et al., 2015). Shortening the dry period has been proposed as a mechanism to reduce milk at the time of dry-off (Annen et al., 2004a). It has also been proposed that shifting milk production from the challenging time after calving to the weeks before could improve early-lactation energy balance and subsequently health and fertility of cows (van Knegsel et al., 2013). Thus, reexamination of DPL for cows in the 21st century is warranted.

More recent retrospective analyses aligned with previous studies, reporting negative associations between short or long dry periods and subsequent lactation performance (Pinedo et al., 2011; Atashi et al., 2013). Although these studies accounted for other explanatory variables (such as parity, calving season, year of calving, previous 305-d milk yield, or herd) to reduce the biases associated with nonrandom assignment of cows to DPL categories, neither were conducted in the United States, nor did they differentiate among reasons for the deviations in DPL. It is known that short or long gestation lengths (GL) are associated with greater incidence of dystocia, stillbirth, retained placenta, and metritis, and lower milk production (Vieira-Neto et al., 2017). As such, it is possible the adverse effects associated with short or long DPL reported by Pinedo et al. (2011) and Atashi et al. (2013) were actually related to biological factors (genetics, stress, or others) causing early or late parturition rather than effects of DPL per se.

To our knowledge, no study has ever evaluated the lactation outcomes associated with DPL while accounting for the reasons underlying the deviation from the target DPL. Incorporation of GL as a reason for DPL deviation may provide insight into which DPL associa- tions are linked to underlying or pre-existing biological processes versus those mainly resulting from management decisions (early dry-off, incorrect recording, or similar). The objective of this study was to determine whether biological and management reasons for a short or long dry period are associated with different effects on subsequent lactation productivity. Our hypothesis was that subsequent lactation productivity would be most hindered by short or long DPL caused by deviations in GL rather than management factors.

\section{MATERIALS AND METHODS}

\section{Dairy Herds and Animals}

A convenience sample of 16 dairies from the Western and Midwestern regions of the United States were used in a retrospective cohort design. Participating herds were identified through nutrition consultants and included based on their willingness to share herd records and the following herd inclusion criteria: Holstein cows, herd size $\geq 900$ cows, use of AI or ability to exclude bull breedings, and at least bimonthly DHIA testing. Descriptive statistics of dairies are presented in Supplemental Table S1 (https://doi.org/10.3168/ jds.2020-18462). Medians for herd size, herd turnover rate, and previous-lactation 305-d mature equivalent (MEq) milk yield were 2,769 cows (range: 928-10,047), $44.3 \%$ (range: 29.1-53.4\%) and $12,816 \mathrm{~kg}$ (range: 11,655-18,615 kg), respectively.

\section{Data Collection}

Previous and subsequent lactation data for cows calving in 2016 were extracted from archived herd records (DairyComp 305, Valley Ag Software, Tulare, CA). Data cleaning was performed on individual dairy data sets in SAS (version 9.4, SAS Institute Inc., Cary, NC) to remove observations that did not satisfy cow-level inclusion criteria. The complete data set totaled 60,773 observations, 28,591 of which were removed. The reasons for removal and percentage of cows removed from the initial 60,773 observations for each reason were as follows: first-lactation cows $(38.8 \%)$, cows not specifically defined as Holstein (2.7\%), duplicate data or information for the second lactation for cows that calved twice in $2016(2.5 \%)$, cows missing GL data $(<0.01 \%)$, cows without a dry period or that were missing DPL data $(0.28 \%)$, and cows with DPL $>280 \mathrm{~d}(0.003 \%)$. Because gestations $<260 \mathrm{~d}$ are generally considered to end in abortions (Gädicke and Monti, 2013), a post hoc removal of observations with GL $<260$ was performed (116 observations, $0.19 \%$ ). 


\section{Treatment Category Determination}

Treatment categorization was conducted on an individual farm basis to account for differences in management and genetics that are reflected in the varied distributions of DPL and GL across farms (Supplemental Figure S1, https://doi.org/10.3168/jds.2020-18462). The UNIVARIATE procedure of SAS was run twice for both DPL and GL: first to remove outliers for both $(>|3|$ SD from the mean) and second to determine short $(>1$ SD below the mean), average (within $\pm 1 \mathrm{SD}$ of the mean), and long ( $>1$ SD above the mean) categories within each herd. Mean DPL and GL used to categorize cows in each farm are listed in Table 1 with their respective SD. Mean DPL for all farms were within industry norms. A $3 \times 3$ factorial design for DPL and GL categories was used to generate the following 9 study groups: (1) short DPL, short $\mathrm{GL}\left(\mathbf{S}_{\mathrm{D}} \mathbf{S}_{\mathrm{G}}, \mathrm{n}=2,123\right)$; (2) short DPL, average $\mathrm{GL}\left(\mathbf{S}_{\mathbf{D}} \mathbf{A}_{\mathbf{G}}, \mathrm{n}=1,418\right)$; (3) short DPL, long GL $\left(\mathrm{S}_{\mathrm{D}} \mathrm{L}_{\mathrm{G}}, \mathrm{n}=50\right)$; (4) average DPL, short $\mathrm{GL}\left(\mathbf{A}_{\mathrm{D}} \mathbf{S}_{\mathrm{G}}, \mathrm{n}=1,759\right) ;(5)$ average DPL, average GL $\left(\mathbf{A}_{\mathbf{D}} \mathbf{A}_{\mathbf{G}}, \mathrm{n}=19,265\right)$; (6) average DPL, long GL $\left(\mathbf{A}_{\mathrm{D}} \mathbf{L}_{\mathrm{G}}, \mathrm{n}=3,325\right)$; (7) long DPL, short $\mathrm{GL}\left(\mathrm{L}_{\mathrm{D}} \mathrm{S}_{\mathrm{G}}, \mathrm{n}\right.$ $=310)$; (8) long DPL, average $\mathrm{GL}\left(\mathbf{L}_{\mathbf{D}} \mathbf{A}_{\mathrm{G}}, \mathrm{n}=2,573\right)$; and long DPL, long $\mathrm{GL}\left(\mathbf{L}_{\mathrm{D}} \mathbf{L}_{\mathrm{G}}, \mathrm{n}=1,719\right)$. Categories $\mathrm{S}_{\mathrm{D}} \mathrm{L}_{\mathrm{G}}$ and $\mathrm{L}_{\mathrm{D}} \mathrm{S}_{\mathrm{G}}$ were not analyzed due to the small number of observations in each and lack of biological plausibility. A total of 32,182 lactating cows from the 16 dairies were used for analysis.

\section{Outcome Variables}

First test day variables evaluated were milk yield (MY1), milk fat and protein concentrations and yields, and SCC. Somatic cell count is reported as somatic cell linear score (LSC1), calculated as $\log _{2}(\mathrm{SCC} / 100)$ +3 (Shook, 1993). Observations were restricted to those with a first test between 5 and 35 DIM. Because no observations had a first test on d 5 or 6 of lactation, DIM at first test actually ranged from 7 to 35 DIM. Similarly, whole-lactation variables investigated included milk yield, milk fat and protein concentrations and yield, and average linear somatic cell count (LSC). For insight into whole-lactation milk production, 305-d MEq milk yield, predicted at third test of lactation, was used (MEq305). The third test was chosen because it included a large proportion of observations, lessening survivor bias, as well as incorporating the precision of data from multiple tests (see Supplemental Table S2, https://doi.org/10.3168/jds.2020-18462). Excluding first test data, milk component concentrations and LSC were averaged across lactation. Whole-lactation milk fat and protein yields were calculated as the average component values multiplied by MEq305.

Reproduction for the lactation period following the studied dry period was evaluated by the following outcome variables: (1) DIM at first service, (2) first service conception risk, and (3) days open, defined as the number of days between calving and the breeding that resulted in pregnancy. Herd retention was analyzed as hazard of leaving the herd, either through death or live culling, and was assessed within the first 60 or $365 \mathrm{~d}$ after calving.

\section{Explanatory Variables}

The explanatory variables can be grouped to consider 3 periods: (1) previous lactation, (2) dry-off, and

Table 1. Mean and SD for dry period and gestation length used to calculate study group by each dairy

\begin{tabular}{|c|c|c|c|c|c|}
\hline \multirow[b]{2}{*}{ Dairy } & \multirow[b]{2}{*}{$\mathrm{n}$} & \multicolumn{2}{|c|}{ Dry period length } & \multicolumn{2}{|c|}{ Gestation length } \\
\hline & & Mean & $\mathrm{SD}$ & Mean & $\mathrm{SD}$ \\
\hline A & 1,550 & 59.2 & 12.7 & 276.8 & 5.1 \\
\hline B & 713 & 54.2 & 7.5 & 274.3 & 5.2 \\
\hline $\mathrm{C}$ & 1,763 & 59.5 & 13.7 & 277.2 & 5.3 \\
\hline D & 1,422 & 50.2 & 11.9 & 275.9 & 4.9 \\
\hline $\mathrm{E}$ & 590 & 61.8 & 7.1 & 276.1 & 5.0 \\
\hline $\mathrm{F}$ & 1,313 & 48.0 & 11.7 & 276.2 & 5.4 \\
\hline $\mathrm{H}$ & 780 & 52.4 & 8.1 & 276.2 & 5.4 \\
\hline I & 1,602 & 56.3 & 12.3 & 276.8 & 5.3 \\
\hline $\mathrm{J}$ & 766 & 58.9 & 15.7 & 278.0 & 5.6 \\
\hline K & 6,345 & 58.1 & 7.4 & 276.9 & 5.1 \\
\hline M & 2,854 & 56.0 & 10.6 & 276.5 & 5.9 \\
\hline $\mathrm{N}$ & 1,566 & 63.3 & 5.6 & 277.3 & 4.9 \\
\hline $\mathrm{O}$ & 3,848 & 60.2 & 15.1 & 277.1 & 5.5 \\
\hline $\mathrm{P}$ & 2,875 & 63.1 & 10.7 & 276.5 & 5.5 \\
\hline Q & 2,263 & 56.4 & 11.6 & 276.7 & 4.8 \\
\hline $\mathrm{R}$ & 2,408 & 56.0 & 5.8 & 276.7 & 5.1 \\
\hline Overall & 32,182 & 57.6 & 11.1 & 276.9 & 5.1 \\
\hline
\end{tabular}


(3) calving and subsequent lactation. Variables from the previous lactation included previous days carried calf, 305-d MEq milk yield (PRVME), days open (PDOPN), and both milk yield and LSC at last test before dry-off (LMILK and LLSC, respectively). The last test before dry-off must have occurred within $40 \mathrm{~d}$ before dry-off, to be considered. Dry period information included DPL and days in the close-up pen. Calving and subsequent lactation information included parity group (categorized as 2 or $3+$ ), fresh month, calf description (female, male, twin), calf dead on arrival (DOA), calving difficulty (CFDIF; yes or no), mastitis at first test (defined as LSC >4.5; yes or no), and PTA for milk yield (PTAM), fat yield, and protein yield. Milk yield at first test was tested as an explanatory variable for first test milk fat and protein models. Quadratic terms were created for all continuous variables and tested in all models for which the respective linear term was included.

\section{Statistical Analysis}

To determine significant predictors of study group assignment, multinomial logistic regression was conducted for each dairy using the LOGISTIC procedure of SAS with the glogit link function. Fixed effects evaluated were parity group, fresh month, calf description, DOA, previous lactation GL, PRVME, and LMILK.

Associations between study group and outcomes of interest were all assessed in STATA/IC 12.1 (StataCorp LLC, College Station, TX). Continuous variables of interest were assessed by multivariable mixed effects regression models, and first service conception risk by a mixed logistic regression mode. Time to event data (days to first service, days open, survival) were analyzed by Cox proportional hazard models and visualized with Kaplan-Meier survival graphs. The hierarchical structure of the data consisted of cows nested within herds. To account for clustering at the herd level, herd was included as a random intercept in mixed models and as a shared frailty term for Cox models.

Multivariable models were constructed for each outcome of interest using variables significant at the $20 \%$ level $(P<0.20)$ in the univariable screen. The main predictor of interest, study group, was forced into all models. All 2-way interactions between study group and other predictors were tested. Manual backward elimination was used to remove all nonsignificant variables $(P>0.05)$ unless they were part of a significant interaction term or their quadratic term was significant. Models were assessed for collinearity using Spearman's correlation coefficient; however, no correlated variables $(|r|>0.80)$ were detected for any of our final models.
Diagnostics of final multivariable linear and logistic mixed effects models involved examination of residuals at both the dairy and the cow level. Predicted values (BLUP) were generated for the random effect (herd), and standardized residuals were calculated for lowerlevel residuals (cow). Both levels of residuals were visually examined to assess model fit and identify potential outliers. Potential outliers were individually assessed for biological plausibility. Those with biologically implausible values were removed from the analysis. Results are presented as the coefficients for all significant variables with means also generated for categorical variables. Pairwise comparisons among study groups were adjusted for multiple comparisons by the method of Bonferroni. Intraclass correlation coefficients were calculated to determine the proportion of total variance in the population that could be attributed to variation between groups.

Time to event data (days to first service, days open, herd retention) were analyzed by Cox proportional hazard models and visualized with Kaplan-Meier survival graphs. The proportional hazards assumption was evaluated both graphically and via statistical assessment using Schoenfeld residuals. To fully understand the main effect of study group and obtain hazard ratios that would represent the Kaplan-Meier graph, a univariable Cox model containing only study group was run for survival models. Kaplan-Meier survival curves were generated for each study group and tested for homogeneity by the Wilcoxon test. To further determine which study groups differed, the univariable Cox model was run several times, each with a different study group as the referent.

\section{RESULTS}

Data analyzed in this study represented 32,182 cows from 16 dairy herds across the Midwestern and Western United States. Distributions of DPL and GL for each study group are shown in Figure 1. Medians and interquartile ranges for DPL $\left(\mathrm{S}_{\mathrm{D}} \mathrm{S}_{\mathrm{G}}=44,40-48 \mathrm{~d} ; \mathrm{S}_{\mathrm{D}} \mathrm{A}_{\mathrm{G}}=\right.$ $46,43-50 \mathrm{~d} ; \mathrm{A}_{\mathrm{D}} \mathrm{S}_{\mathrm{G}}=53,48-56 \mathrm{~d} ; \mathrm{A}_{\mathrm{D}} \mathrm{A}_{\mathrm{G}}=56,51-60$ $\mathrm{d} ; \mathrm{A}_{\mathrm{D}} \mathrm{L}_{\mathrm{G}}=60,57-64 \mathrm{~d} ; \mathrm{L}_{\mathrm{D}} \mathrm{A}_{\mathrm{G}}=77,70-85 \mathrm{~d} ; \mathrm{L}_{\mathrm{D}} \mathrm{L}_{\mathrm{G}}=$ $70,67-77 \mathrm{~d})$ and $\mathrm{GL}\left(\mathrm{S}_{\mathrm{D}} \mathrm{S}_{\mathrm{G}}=268,266-270 \mathrm{~d} ; \mathrm{S}_{\mathrm{D}} \mathrm{A}_{\mathrm{G}}\right.$ $=273,272-275 \mathrm{~d} ; \mathrm{A}_{\mathrm{D}} \mathrm{S}_{\mathrm{G}}=270,268-271 \mathrm{~d} ; \mathrm{A}_{\mathrm{D}} \mathrm{A}_{\mathrm{G}}=$ $277,275-279 \mathrm{~d} ; \mathrm{A}_{\mathrm{D}} \mathrm{L}_{\mathrm{G}}=284,283-285 \mathrm{~d} ; \mathrm{L}_{\mathrm{D}} \mathrm{A}_{\mathrm{G}}=277$, 275-280 d; $\mathrm{L}_{\mathrm{D}} \mathrm{L}_{\mathrm{G}}=284,283-287 \mathrm{~d}$ ) reflect appropriate DPL and GL categorization.

Because study group classification was determined on an individual herd basis, associated factors were also investigated on the individual herd basis. Factors that predicted study group were generally similar across herds; however, the direction of prediction for the study 

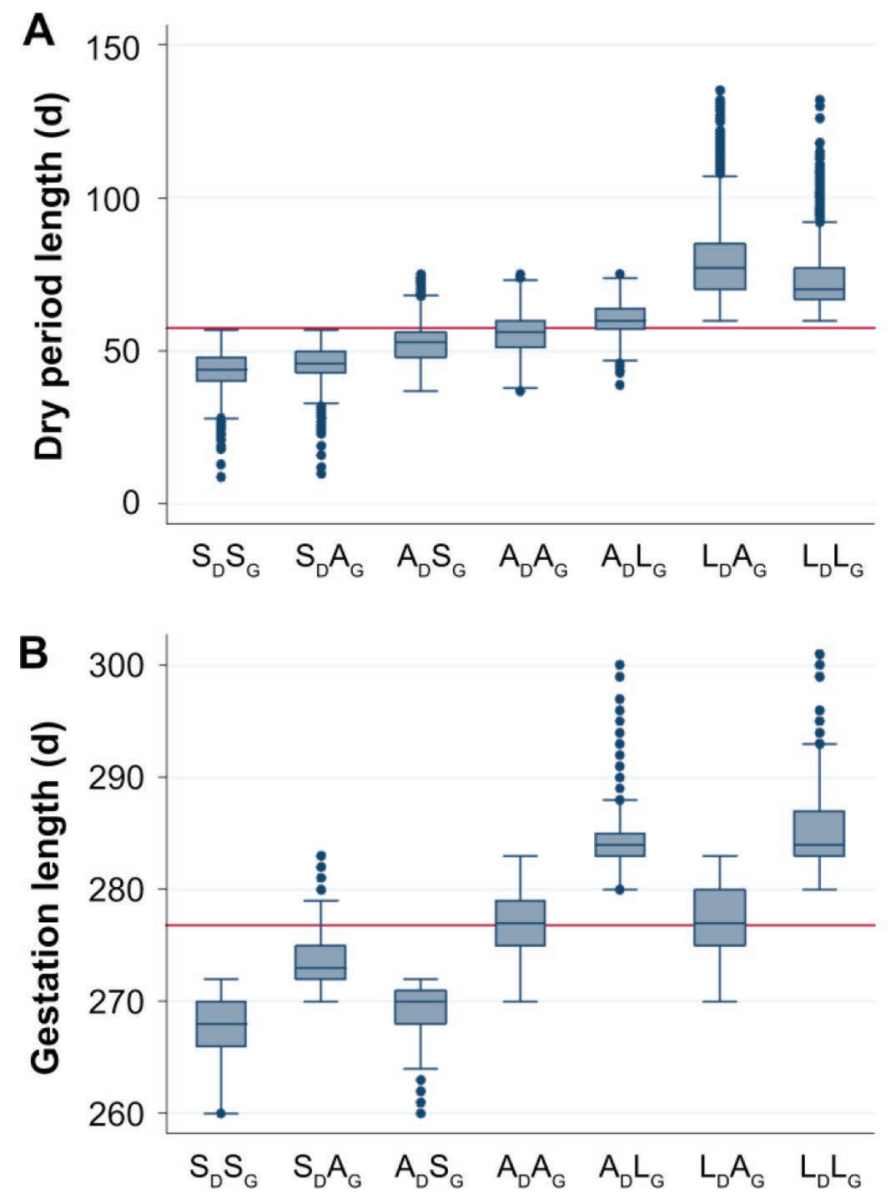

Figure 1. Box-and-whisker plots of (A) dry period length (DPL) and (B) gestation length (GL) for each study group. The horizontal red line indicates the data set mean $(\mathrm{DPL}=57.6, \mathrm{GL}=276.9)$. For the box plots, line within the box indicates the median; top and bottom of the box indicate 75 th and 25th percentiles, respectively; whiskers above and below the box indicate the upper adjacent value [quartile $3+1.5$ (interquartile range)] and lower adjacent value [quartile $1-1.5$ (interquartile range)], respectively; and dots outside the whiskers represent outliers. Study groups were categorized as $\mathrm{S}_{\mathrm{D}} \mathrm{S}_{\mathrm{G}}$ $=$ short DPL, short GL; $\mathrm{S}_{\mathrm{D}} \mathrm{A}_{\mathrm{G}}=$ short DPL, average GL; $\mathrm{A}_{\mathrm{D}} \mathrm{S}_{\mathrm{G}}=$ average DPL, short GL; $A_{D} A_{G}=$ average DPL, average GL; $A_{D} L_{G}=$ average DPL, long GL; $\mathrm{L}_{\mathrm{D}} \mathrm{A}_{\mathrm{G}}=$ long DPL, average GL; $\mathrm{L}_{\mathrm{D}} \mathrm{L}_{\mathrm{G}}=$ long DPL, long GL.

group was not consistent across dairies. Predictive factors were PRVME, PDOPN, previous lactation GL, LMILK, DOA, calf description, and parity group $(P<$ 0.05). The full regression model is available at https:// figshare.com/s/fb46c107417262a00f85. Generally, cows in lactation $3+$ had greater odds of being in $\mathrm{L}_{\mathrm{D}} \mathrm{A}_{\mathrm{G}}$, $\mathrm{L}_{\mathrm{D}} \mathrm{L}_{\mathrm{G}}$, and $\mathrm{A}_{\mathrm{D}} \mathrm{L}_{\mathrm{G}}$; cows bearing male calves had greater odds of being in a long GL group; twin-bearing cows had greater odds of being in either short GL group; cows with a DOA calf had greater odds of being in either of the short GL groups and $A_{D} L_{G}$; greater milk yield at last test was associated with greater odds of being in either short DPL group or $\mathrm{A}_{\mathrm{D}} \mathrm{L}_{\mathrm{G}}$; and greater previous-lactation GL was associated with greater odds of the long GL groups. Predicted transmitting ability for milk production was tested but not retained for any herd. In only one dairy did the aforementioned variables not predict study group (dairy E).

\section{First Test Lactation Variables}

Full final regression models for all milk lactation outcomes are available at https://figshare.com/s/ fb46c107417262a00f85. The main effects of study group, interactions with study group, and study group means for lactation outcomes at first test and over $305 \mathrm{~d}$ are presented in Tables 2 and 3, respectively.

The association between MY1 and study group was dependent on PRVME, LMILK, and PDOPN $(P<$ 0.001; Figure 2). A positive relationship appeared between MY1 and PRVME, but the magnitude was less for cows with a short DPL or GL, and least for cows with both a short DPL and GL. The study group $\times$ LMILK and study group $\times$ PDOPN interactions for MY1 were similar. Although MY1 either increased or was similar across the LMILK and PDOPN ranges for other study groups, MY1 progressively decreased for $\mathrm{S}_{\mathrm{D}} \mathrm{A}_{\mathrm{G}}$ cows as LMILK or PDOPN increased. Although the main effect of study group was not significant $(P$ $=0.16), \mathrm{S}_{\mathrm{D}} \mathrm{S}_{\mathrm{G}}$ had the least mean MY1, followed by $A_{D} S_{G}$ and $S_{D} A_{G}$; these means are consistent with the results shown in the interaction graphs (Figure 2). Milk at first test was greater for cows in lactation $3+$ than for second-lactation cows ( 43.4 vs. $40.7 \pm 0.96 \mathrm{~kg}$ ), was less for cows bearing twins (39.5 vs. $42.2 \pm 1.01 \mathrm{~kg}$ ) or a dead calf ( 40.0 v. $42.3 \pm 0.97 \mathrm{~kg})$, decreased with mastitis at first test (41.1 vs. $42.7 \pm 0.97)$, and varied by month of parturition (all $P<0.001$ ).

Milk fat concentration decreased with increasing milk yield at first test. The slope reflecting this relationship was similar across study groups, except for a steeper slope for $\mathrm{L}_{\mathrm{D}} \mathrm{A}_{\mathrm{G}}$ (Figure $3 \mathrm{~A}$ ). The study group $\times$ PDOPN interaction indicated relatively constant milk fat concentration across PDOPN $\left(\mathrm{A}_{\mathrm{D}} \mathrm{A}_{\mathrm{G}}\right.$ and $\left.\mathrm{A}_{\mathrm{D}} \mathrm{S}_{\mathrm{G}}\right)$ or increases as PDOPN increased $\left(\mathrm{S}_{\mathrm{D}} \mathrm{S}_{\mathrm{G}}, \mathrm{S}_{\mathrm{D}} \mathrm{A}_{\mathrm{G}}, \mathrm{A}_{\mathrm{D}} \mathrm{L}_{\mathrm{G}}\right.$, $\mathrm{L}_{\mathrm{D}} \mathrm{A}_{\mathrm{G}}, \mathrm{L}_{\mathrm{D}} \mathrm{L}_{\mathrm{G}}$; Figure $3 \mathrm{~B}$ ). Again the interaction was most drastic for $\mathrm{L}_{\mathrm{D}} \mathrm{A}_{\mathrm{G}}$. First test milk fat concentration was greater for cows with $3+$ lactations (4.01 vs. 4.09 $\pm 0.10 \%)$, lowest for cows calving in summer months, less for twin-bearing cows (3.90 vs. $4.07 \pm 0.10 \%$ ), and greater for cows with mastitis at first test (4.03 vs. 4.15 $\pm 0.10 \%)$, and this trait increased with increasing PTA fat yield but decreased with PTAM and PRVME (all $P<0.001)$.

Milk fat yield at first test was greatest for $\mathrm{L}_{\mathrm{D}} \mathrm{L}_{\mathrm{G}}$ and $A_{D} L_{G}$, intermediate for $S_{D} A_{G}, A_{D} A_{G}, L_{D} A_{G}$, decreased for $A_{D} S_{G}$, and least for $S_{D} S_{G}(P<0.001)$. Milk fat yield 
Olagaray et al.: DRY PERIOD LENGTH

11862

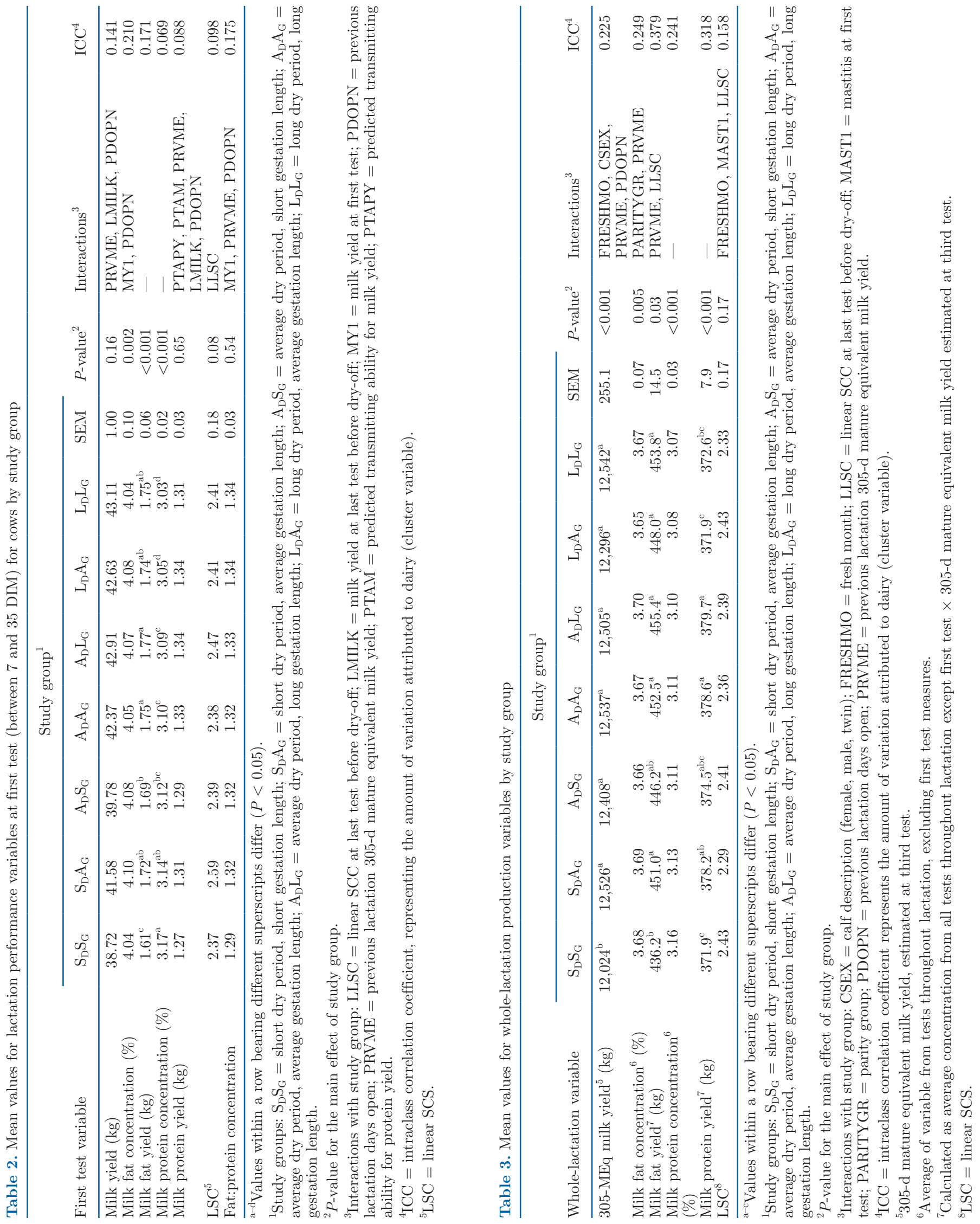




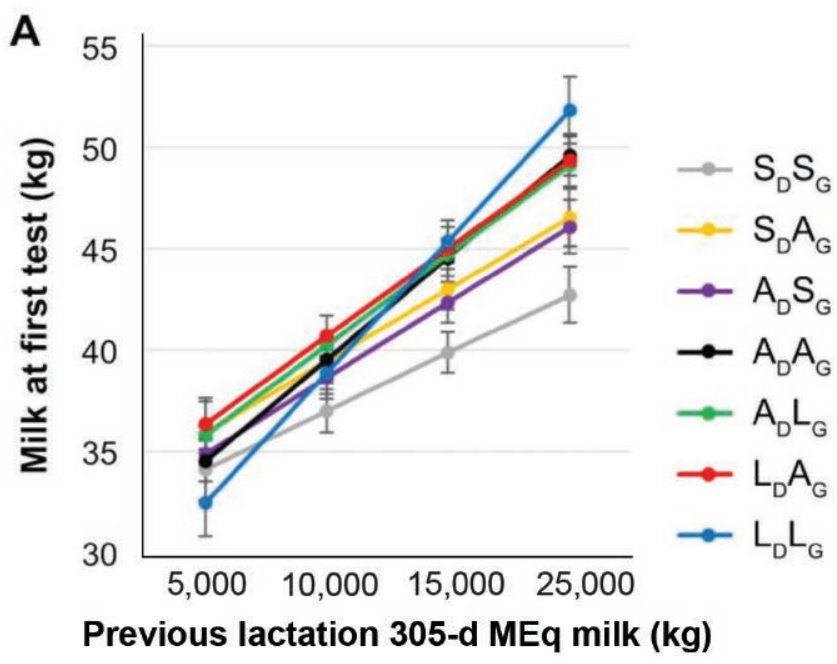

B
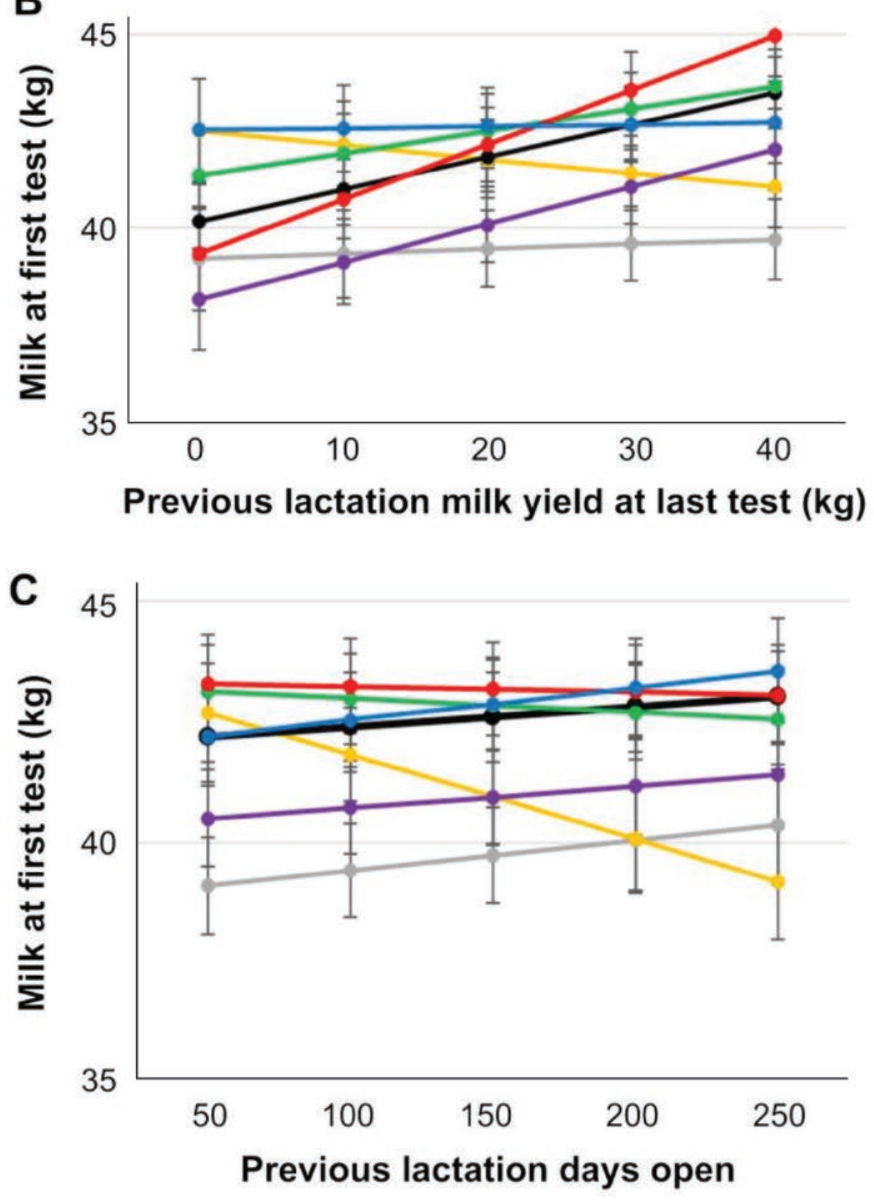

Figure 2. The association between milk yield at first test and study group was dependent on (A) previous lactation 305-d mature equivalent (MEq) milk yield, (B) milk yield at last test before dry-off, and $(\mathrm{C})$ previous lactation days open (all $P<0.001$ ). Values are LSM \pm SEM. Study group was categorized as follows: $\mathrm{S}_{\mathrm{D}} \mathrm{S}_{\mathrm{G}}=$ short dry period, short gestation length; $\mathrm{S}_{\mathrm{D}} \mathrm{A}_{\mathrm{G}}=$ short dry period, average gestation length; $A_{D} S_{G}=$ average dry period, short gestation length; $A_{D} A_{G}$ $=$ average dry period, average gestation length; $\mathrm{A}_{\mathrm{D}} \mathrm{L}_{\mathrm{G}}=$ average dry period, long gestation length; $\mathrm{L}_{\mathrm{D}} \mathrm{A}_{\mathrm{G}}=$ long dry period, average gestation length; $\mathrm{L}_{\mathrm{D}} \mathrm{L}_{\mathrm{G}}=$ long dry period, long gestation length.

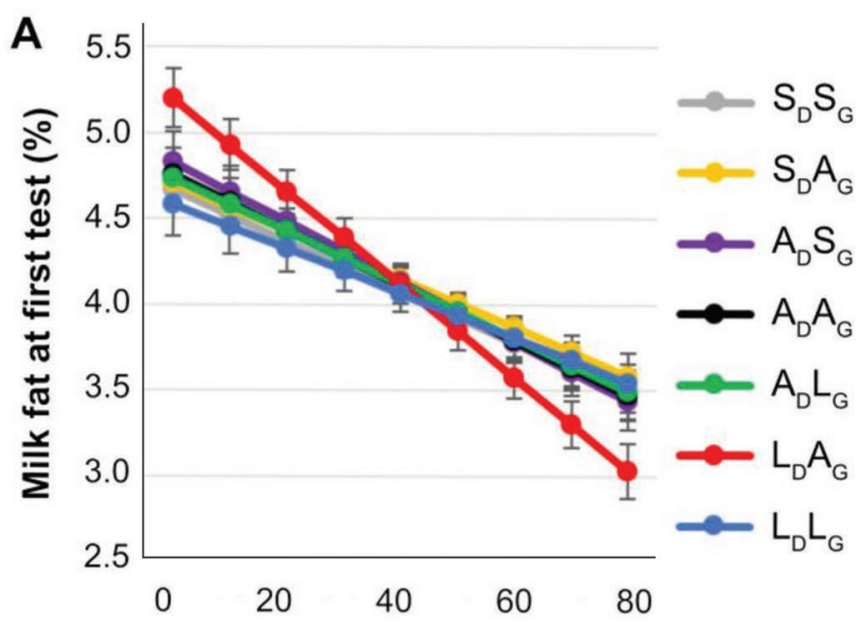

Milk yield at first test $(\mathrm{kg} / \mathrm{d})$

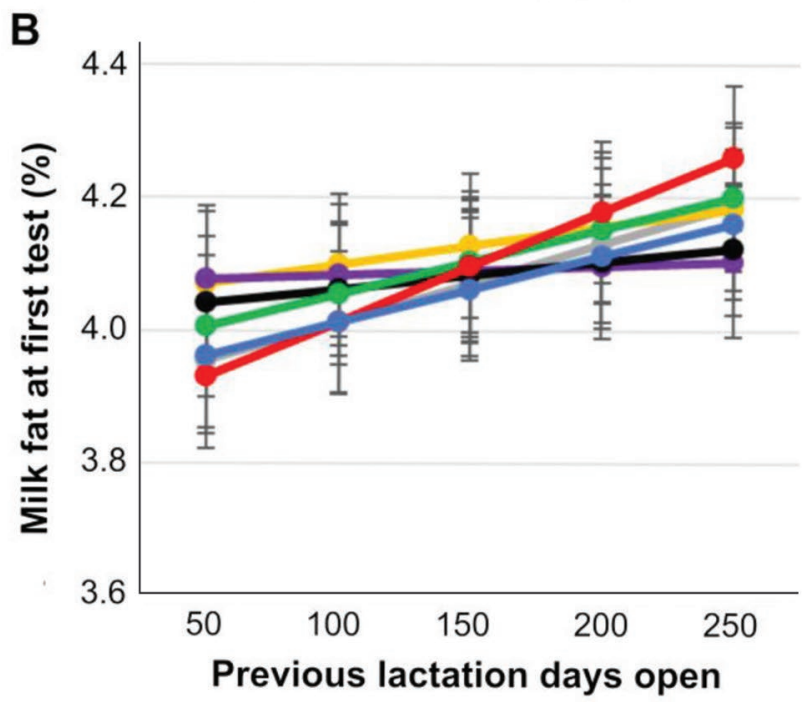

Figure 3. Association between study group and milk fat concentration at first test depended on (A) milk yield at first test and (B) previous lactation days open (both $P<0.001$ ). Values are LSM \pm SEM. Study group was categorized as follows: $\mathrm{S}_{\mathrm{D}} \mathrm{S}_{\mathrm{G}}=$ short dry period, short gestation length; $\mathrm{S}_{\mathrm{D}} \mathrm{A}_{\mathrm{G}}=$ short dry period, average gestation length; $\mathrm{A}_{\mathrm{D}} \mathrm{S}_{\mathrm{G}}=$ average dry period, short gestation length; $\mathrm{A}_{\mathrm{D}} \mathrm{A}_{\mathrm{G}}=$ average dry period, average gestation length; $\mathrm{A}_{\mathrm{D}} \mathrm{L}_{\mathrm{G}}=$ average dry period, long gestation length; $\mathrm{L}_{\mathrm{D}} \mathrm{A}_{\mathrm{G}}=$ long dry period, average gestation length; $\mathrm{L}_{\mathrm{D}} \mathrm{L}_{\mathrm{G}}=$ long dry period, long gestation length).

at first test was greater for cows with $3+$ lactations (1.81 vs. $1.66 \pm 0.10 \mathrm{~kg} / \mathrm{d})$ and less for cows calving twins (1.59 vs. $1.75 \pm 0.06 \mathrm{~kg} / \mathrm{d}$ ), cows with a calf DOA (1.65 vs. $1.74 \pm 0.06 \mathrm{~kg} / \mathrm{d})$, and cows with mastitis at first test $(1.71$ vs. $1.75 \pm 0.06 \mathrm{~kg} / \mathrm{d}$; all $P<0.001)$. Milk fat yield increased with LMILK, PRVME, and PDOPN $(P<0.001)$; however, the negative coefficient for the quadratic term of PDOPN $(P<0.001)$ indicates a threshold for the positive relationship between PDOPN and first test milk fat yield. 
Differences in milk protein concentration at first test by study group were generally inversely related to differences in MY1 $(P<0.001)$, with greatest concentrations for $\mathrm{S}_{D} \mathrm{~S}_{\mathrm{G}}$, least for $\mathrm{L}_{\mathrm{D}} \mathrm{A}_{\mathrm{G}}$ and $\mathrm{L}_{\mathrm{D}} \mathrm{L}_{\mathrm{G}}$, and intermediate for $S_{D} A_{G}, A_{D} S_{G}, A_{D} A_{G}$, and $A_{D} L_{G}$. Other factors associated with milk protein concentration at first test also reflected dilution by milk yield and included decreases for cows in their third lactation or greater (3.09 vs. $3.11 \pm 0.02 \%$ ), increased milk protein concentration for cows with calves DOA (3.14 vs. $3.10 \pm 0.03 \%)$ and with mastitis at first test $(3.17$ vs. $3.08 \pm 0.02 \%)$, and differences by fresh month $(P \leq 0.002)$. Milk protein concentration decreased with increasing MY1 and PRVME but increased with increases in PTA protein percent and PTA protein yield $(P<0.001)$. Previous lactation days open and LMILK were positively related to milk protein concentration at first test, but quadratic terms indicate a threshold for which the relationship remains positive $(P \leq 0.01)$.

Milk protein yield at first test was least for $\mathrm{S}_{\mathrm{D}} \mathrm{S}_{\mathrm{G}}$ and $A_{D} S_{G}$, intermediate for $S_{D} A_{G}$ and $L_{D} L_{G}$, and greatest for $\mathrm{A}_{\mathrm{D}} \mathrm{A}_{\mathrm{G}}, \mathrm{A}_{\mathrm{D}} \mathrm{L}_{\mathrm{G}}$, and $\mathrm{L}_{\mathrm{D}} \mathrm{A}_{\mathrm{G}}(P<0.001)$. We detected an interaction with PTA protein yield in which milk protein yield increased as PTA protein yield increased; however, the slope was greatest for $\mathrm{S}_{\mathrm{D}} \mathrm{S}_{\mathrm{G}}(P=0.03$; Supplemental Figure S2A, https://doi.org/10.3168/jds .2020-18462). Protein yield was either similar across PTAM range $\left(A_{D} S_{G}\right.$ and $\left.L_{D} L_{G}\right)$, or decreased with increasing PTAM $\left(\mathrm{S}_{D} \mathrm{~S}_{\mathrm{G}}, \mathrm{A}_{\mathrm{D}} \mathrm{A}_{\mathrm{G}}, \mathrm{A}_{\mathrm{D}} \mathrm{L}_{\mathrm{G}}\right.$, and $\left.\mathrm{L}_{\mathrm{D}} \mathrm{A}_{\mathrm{G}}\right)$, especially for $\mathrm{S}_{\mathrm{D}} \mathrm{S}_{\mathrm{G}}(P<0.001$; Supplemental Figure S2B, https://doi.org/10.3168/jds.2020-18462). Milk protein yield was similar across treatments at PRVME of $15,000 \mathrm{~kg}$, but $\mathrm{S}_{\mathrm{D}} \mathrm{A}_{\mathrm{G}}$ and $\mathrm{A}_{\mathrm{D}} \mathrm{L}_{\mathrm{G}}$ had greater protein yield among cows with greater PRVME, yet $S_{D} A_{G}$ had the least protein yield among cows with lesser PRVME (Figure 4A). Interactions with LMILK and PDOPN largely reflected observed interactions for MY1. Increases in LMILK were associated with increased milk protein yield for all study groups except for $\mathrm{S}_{\mathrm{D}} \mathrm{A}_{\mathrm{G}}$, which decreased $(P<0.001$; Figure $4 \mathrm{~B})$. Similarly, despite little difference across PDOPN for most study groups, increased PDOPN was associated with decreased milk protein yield at first test for $\mathrm{S}_{\mathrm{D}} \mathrm{A}_{\mathrm{G}}(P=0.02$; Figure $4 \mathrm{C})$.

Overall, LSC1 was positively related to LLSC at last test before dry-off, but LSC1 was greatest for $\mathrm{S}_{\mathrm{D}} \mathrm{A}_{\mathrm{G}}$ cows across the range of LLSC ( $P=0.004$; Supplemental Figure S3, https://doi.org/10.3168/jds.2020-18462). We found that LSC1 was greatest in cows with $3+$ lactations (2.69 vs. $2.06 \pm 0.17)$ and cows that experienced CFDIF (2.46 vs. $2.38 \pm 0.17$ ), lesser in cows with a calf DOA (2.12 vs. $2.41 \pm 0.18)$, and varied by fresh month. We found LSC1 to be least for October calvings, greatest for January calvings, and intermedi-

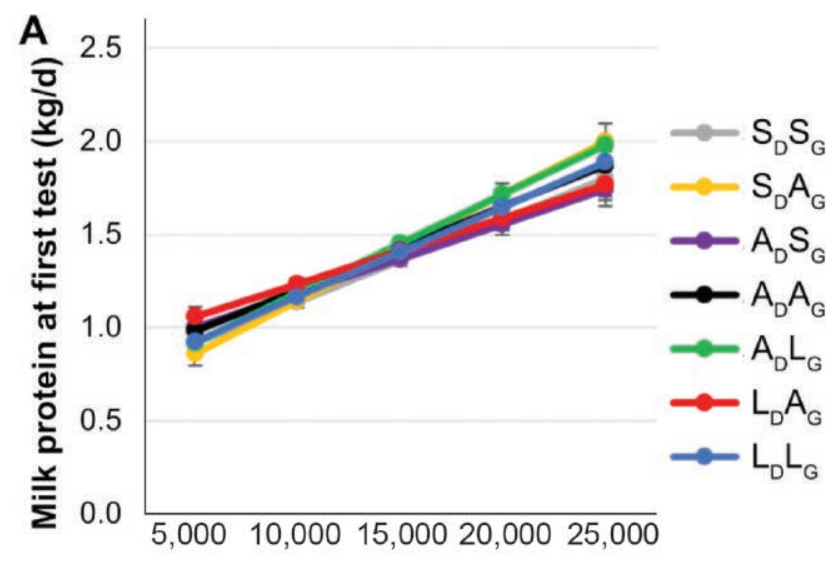

Previous lactation 305-d MEq milk (kg)
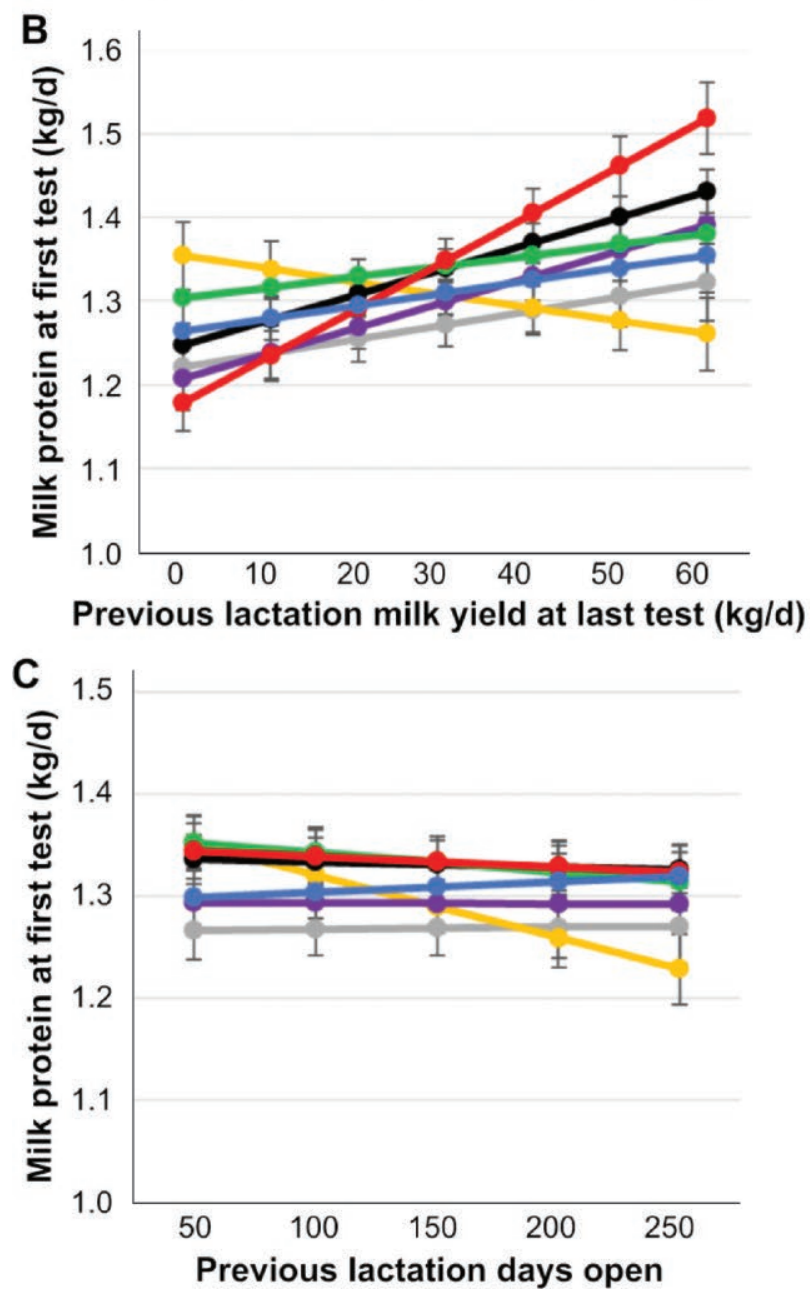

Figure 4. Associations between study group and milk protein yield at first test were dependent on (A) previous lactation 305-d mature equivalent $(\mathrm{MEq})$ milk yield $(P<0.001)$, (B) milk at last test before dry-off $(P<0.001)$, and $(\mathrm{C})$ previous lactation days open $(P=0.02)$. Values are LSM \pm SEM. Study group was categorized as follows: $\mathrm{S}_{\mathrm{D}} \mathrm{S}_{\mathrm{G}}$ $=$ short dry period, short gestation length; $\mathrm{S}_{\mathrm{D}} \mathrm{A}_{\mathrm{G}}=$ short dry period, average gestation length; $\mathrm{A}_{\mathrm{D}} \mathrm{S}_{\mathrm{G}}=$ average dry period, short gestation length; $A_{D} A_{G}=$ average dry period, average gestation length; $A_{D} L_{G}=$ average dry period, long gestation length; $\mathrm{L}_{\mathrm{D}} \mathrm{A}_{\mathrm{G}}=$ long dry period, average gestation length; $\mathrm{L}_{\mathrm{D}} \mathrm{L}_{\mathrm{G}}=$ long dry period, long gestation length. 

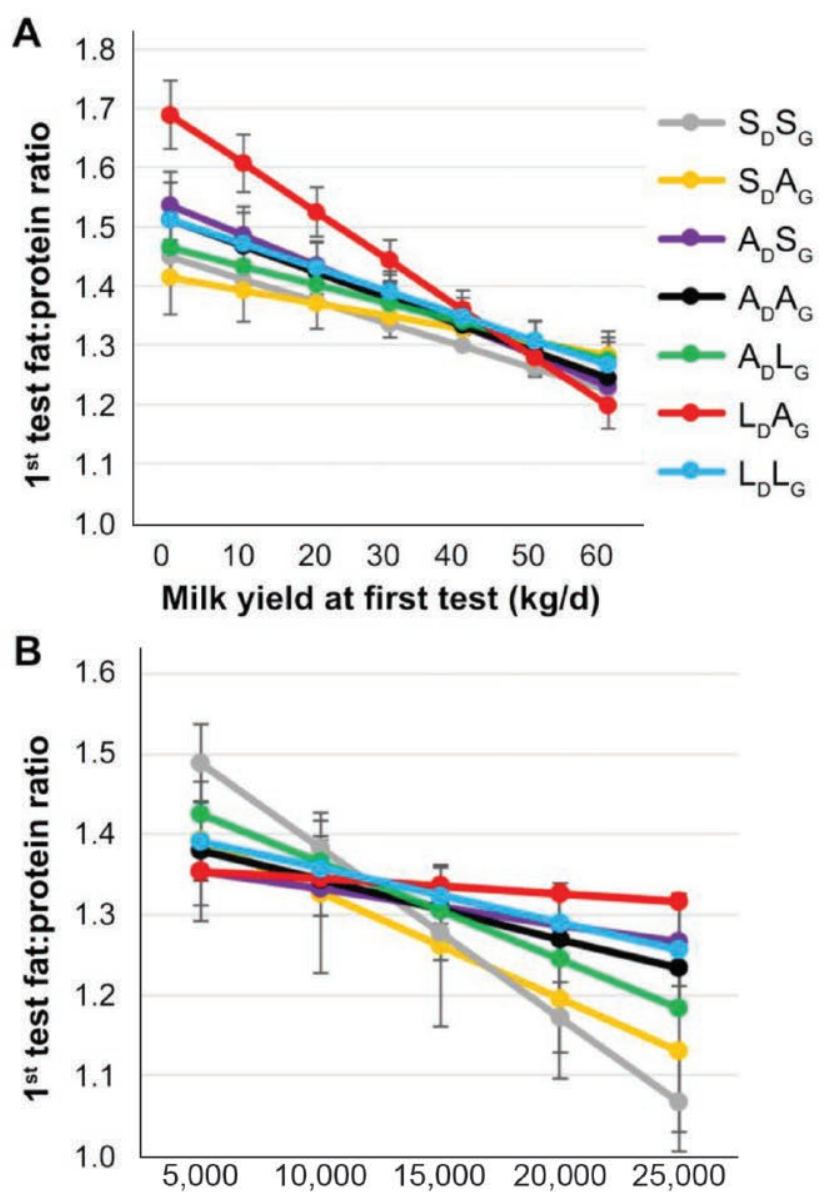

Previous lactation 305-d MEq milk (kg)

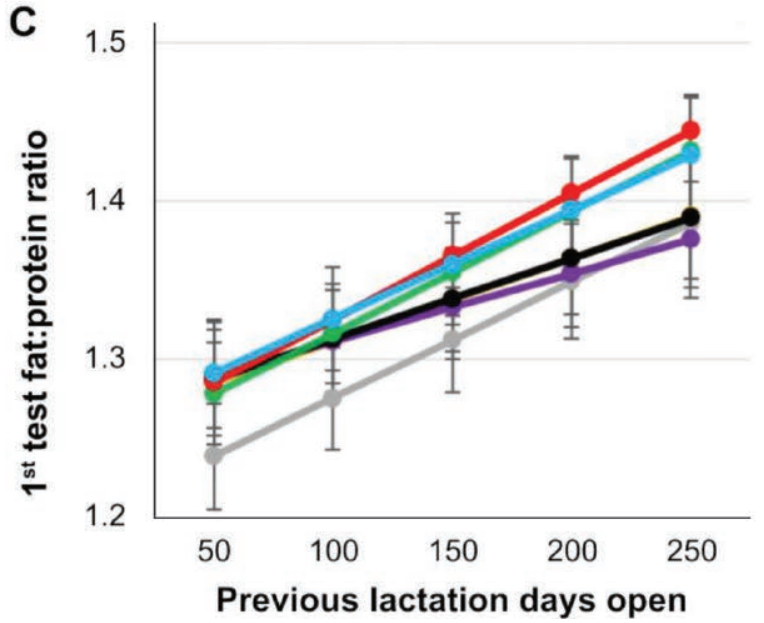

Figure 5. Association between study group and fat:protein concentration at first test of lactation with (A) milk yield at first test, (B) previous lactation 305-d mature equivalent (MEq) milk yield, and (C) previous lactation days open. Values are LSM \pm SEM. Study group was categorized as follows: $S_{D} S_{G}=$ short dry period, short gestation length: $S_{D} A_{G}=$ short dry period, average gestation length: $A_{D} S_{G}=a v-$ erage dry period, short gestation length; $A_{D} A_{G}=$ average dry period, average gestation length; $A_{D} L_{G}=$ average dry period, long gestation length; $\mathrm{L}_{\mathrm{D}} \mathrm{A}_{\mathrm{G}}=$ long dry period, average gestation length; $\mathrm{L}_{\mathrm{D}} \mathrm{L}_{\mathrm{G}}=$ long dry period, long gestation length. ate the remainder of the year $(P \leq 0.05)$. Milk yield at first test was inversely associated with LSC1, whereas PDOPN was positively associated with LSC1.

Associations between study group and fat:protein ratio at first test (FP1) were investigated to provide some insight into early-lactation metabolic status. Study groups did not differ in FP1 overall $(P=0.54)$ but, rather, interacted with MY1, PRVME, and PDOPN $(P \leq 0.01$; Figure 5$)$. The $\mathrm{L}_{\mathrm{D}} \mathrm{A}_{\mathrm{G}}$ study group had greater FP1 when MY1 was less than $40 \mathrm{~kg}$, was similar across the PRVME range, but increased greatly with increased PDOPN.

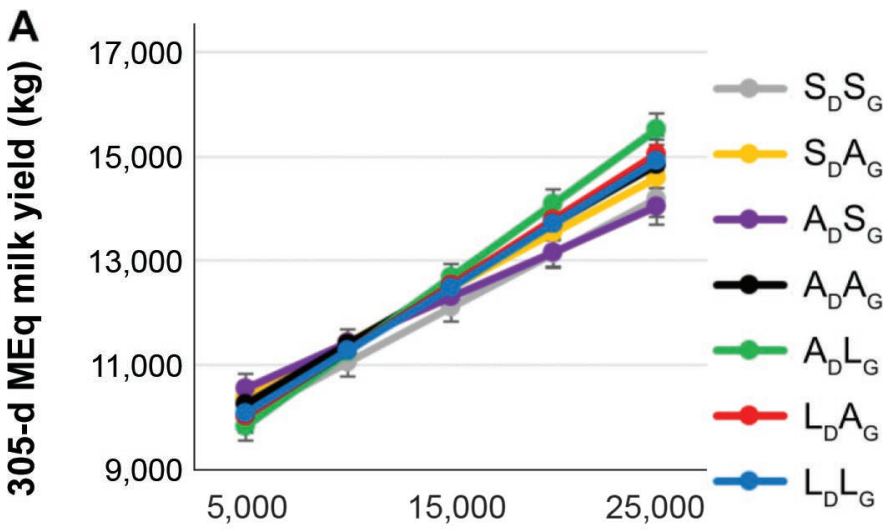

Previous lactation 305-d MEq milk (kg)

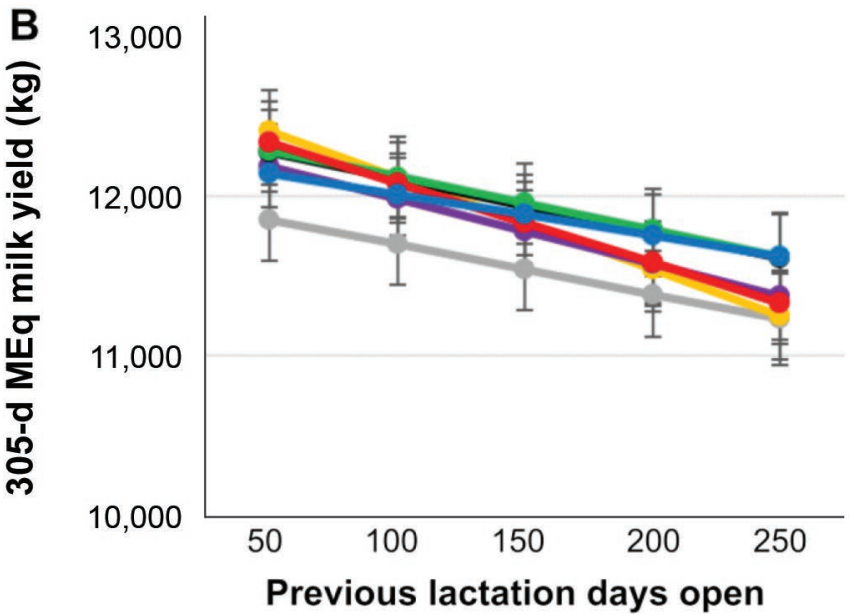

Figure 6. Association between study group and 305-d mature equivalent $(\mathrm{MEq})$ milk yield predicted at third test of lactation interacted with (A) previous lactation 305-d MEq milk production and (B) previous lactation days open. Values are LSM \pm SEM. Study group was categorized as follows: $\mathrm{S}_{\mathrm{D}} \mathrm{S}_{\mathrm{G}}=$ short dry period, short gestation length; $\mathrm{S}_{\mathrm{D}} \mathrm{A}_{\mathrm{G}}=$ short dry period, average gestation length; $\mathrm{A}_{\mathrm{D}} \mathrm{S}_{\mathrm{G}}=\mathrm{av}-$ erage dry period, short gestation length; $A_{D} A_{G}=$ average dry period, average gestation length; $A_{D} L_{G}=$ average dry period, long gestation length; $\mathrm{L}_{\mathrm{D}} \mathrm{A}_{\mathrm{G}}=$ long dry period, average gestation length; $\mathrm{L}_{\mathrm{D}} \mathrm{L}_{\mathrm{G}}=$ long dry period, long gestation length. 


\section{Whole-Lactation Variables}

Full final regression models for whole-lactation variables are available at https://figshare.com/s/ fb46c107417262a00f85, with study group means summarized in Table 3. Overall MEq305 was least for $\mathrm{S}_{\mathrm{D}} \mathrm{S}_{\mathrm{G}}$ cows compared with all other study groups $(P<$ $0.001)$. The association between milk production and study group did, however, interact with fresh month, calf description, PRVME, and PDOPN $(P \leq 0.02)$. No clear pattern in the study group $\times$ fresh month interaction was detected. Study group differences for cows birthing female calves mirrored overall differences, with $305 \mathrm{MEq}$ lowest for $\mathrm{S}_{\mathrm{D}} \mathrm{S}_{\mathrm{G}}$ compared with all other study groups. Within cows birthing male calves, 305MEq was again least for $S_{D} S_{G}$ but greatest for $A_{D} L_{G}$, and intermediate for all other study groups. We detected no difference in milk production among study groups for twin-bearing cows. Unsurprisingly, 305MEq was positively associated with PRVME, but slopes were greater for cows with any combination of average and long DPL and GL compared with cows with short GL (Figure $6 \mathrm{~A})$. As PDOPN increased, milk production decreased; however, cows with long GL $\left(\mathrm{A}_{D} \mathrm{~L}_{\mathrm{G}}\right.$ and $\left.\mathrm{L}_{\mathrm{D}} \mathrm{L}_{\mathrm{G}}\right)$ were least influenced by increasing PDOPN (Figure 6B). Predicted MEq305 milk was lesser for cows with 3+ lactations compared with second-lactation cows $(11,833$ vs. $12,045 \pm 250 \mathrm{~kg})$, cows with a calf DOA $(12,160$ vs. $12,502 \pm 256 \mathrm{~kg}$ ), and cows with mastitis at first test $(12,197$ vs. $12,604 \pm 250 \mathrm{~kg}$; all $P<0.001)$. Milk increased with PTAM and LMILK $(P<0.001)$.

Average fat concentration varied by study group and study group interactions with both parity group and PRVME $(P \leq 0.02)$. No study group differences were detectable among second-lactation cows, but for cows in their third lactation or greater, average milk fat concentration was greatest for $A_{D} A_{G}$ and $A_{D} L_{G}$ cows, least for $L_{D} A_{G}$, and intermediate for the others. Average fat concentration decreased with increased PRVME, with decreases greatest for $\mathrm{S}_{\mathrm{D}} \mathrm{S}_{\mathrm{G}}$ and $\mathrm{A}_{\mathrm{D}} \mathrm{L}_{\mathrm{G}}$ (Supplemental Figure S4, https://doi.org/10.3168/jds.2020-18462). Additional factors associated with increases in average fat concentration were PTA fat yield and LMILK, whereas PTAM was inversely associated $(P \leq 0.03)$, and fat concentration also differed by fresh month.

Whole-lactation fat yield was least for $\mathrm{S}_{\mathrm{D}} \mathrm{S}_{\mathrm{G}}$, intermediate for $A_{D} S_{G}$, and greater for other study groups $(P$ $=0.03)$. Although whole-lactation fat yield increased with PRVME, the degree of increase was least for $\mathrm{S}_{\mathrm{D}} \mathrm{S}_{\mathrm{G}}$ and $\mathrm{A}_{\mathrm{D}} \mathrm{S}_{\mathrm{G}}(P=0.02$; Figure $7 \mathrm{~A})$. Whole-lactation fat yield decreased with greater LLSC, with the greatest decrease for $\mathrm{A}_{\mathrm{D}} \mathrm{S}_{\mathrm{G}}$ (Figure $7 \mathrm{~B}$ ). Decreased fat yield was associated with parity $3+(445.7$ vs. $456.7 \pm 14.3 \mathrm{~kg})$, calf DOA (441.9 vs. $451.2 \pm 14.6 \mathrm{~kg}$ ), mastitis at first test (446.2 vs. $452.1 \pm 14.4 \mathrm{~kg})$, PTAM, and PDOPN, and increased fat yield was associated with LMILK and DIM when cows left the herd $(P \leq 0.03)$.

Average protein concentration was greatest for cows with a short dry period, intermediate with an average dry period, and lowest for cows with a long dry period $(P<0.001)$. Additional associations (all $P \leq 0.01)$, such as decreased protein concentration for cows with $3+$ lactations (3.10 vs. $3.12 \pm 0.03 \%)$ and cows bearing live singletons (3.11 vs. $3.13 \pm 0.03 \%$ ) could be attributed to dilution, as milk yield effects were opposite. Milk protein concentration was positively associated with PTA protein and yield variables and with LMILK, but negatively associated with PTA milk yield, PRVME, and PDOPN $(P \leq 0.01)$.

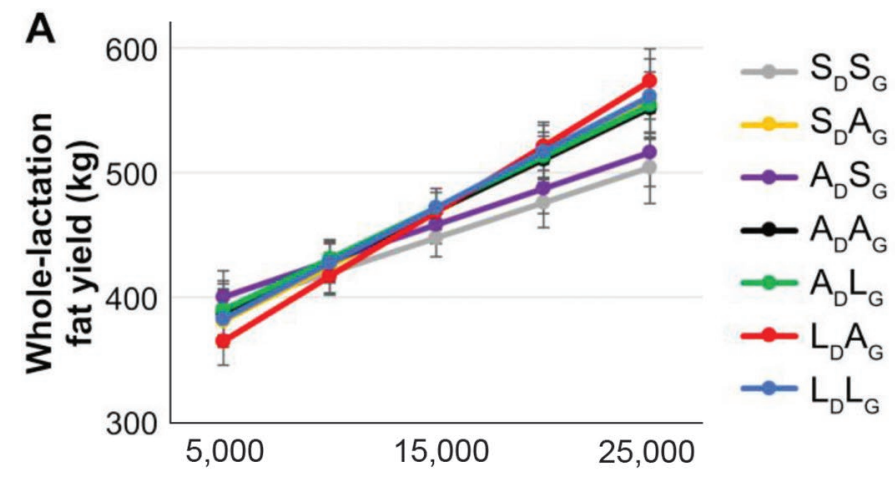

Previous lactation 305-d MEq milk (kg)

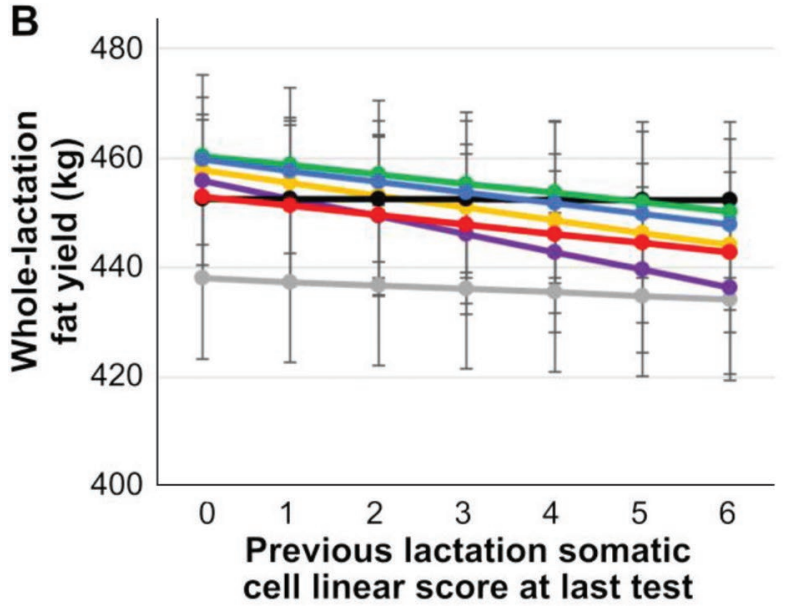

Figure 7. Association between study group and whole-lactation milk fat yield interacted with (A) previous lactation 305-d mature equivalent (MEq) milk production and (B) somatic cell linear score (LSC) at last test before dry-off. Values are LSM \pm SEM. Study group was categorized as follows: $\mathrm{S}_{\mathrm{D}} \mathrm{S}_{\mathrm{G}}=$ short dry period, short gestation length; $\mathrm{S}_{\mathrm{D}} \mathrm{A}_{\mathrm{G}}=$ short dry period, average gestation length; $\mathrm{A}_{\mathrm{D}} \mathrm{S}_{\mathrm{G}}=\mathrm{av}$ erage dry period, short gestation length; $\mathrm{A}_{\mathrm{D}} \mathrm{A}_{\mathrm{G}}=$ average dry period, average gestation length; $\mathrm{A}_{\mathrm{D}} \mathrm{L}_{\mathrm{G}}=$ average dry period, long gestation length; $\mathrm{L}_{\mathrm{D}} \mathrm{A}_{\mathrm{G}}=$ long dry period, average gestation length; $\mathrm{L}_{\mathrm{D}} \mathrm{L}_{\mathrm{G}}=$ long dry period, long gestation length. 
Whole-lactation protein yield was greatest for $A_{D} A_{G}$ and $\mathrm{A}_{\mathrm{D}} \mathrm{L}_{\mathrm{G}}$, least for $\mathrm{S}_{\mathrm{D}} \mathrm{S}_{\mathrm{G}}$ and $\mathrm{L}_{\mathrm{D}} \mathrm{A}_{\mathrm{G}}$, and intermediate for $\mathrm{L}_{\mathrm{D}} \mathrm{L}_{\mathrm{G}}, \mathrm{S}_{\mathrm{D}} \mathrm{A}_{\mathrm{G}}, \mathrm{A}_{\mathrm{D}} \mathrm{S}_{\mathrm{G}}(P<0.001)$. Protein yield was less for cows in lactation $3+(371.8$ vs. $383.2 \pm 7.8 \mathrm{~kg})$ and for cows with mastitis at first test (375.8 vs. 377.8 $\pm 7.8 \mathrm{~kg}$ ), and differed by fresh month (all $P \leq 0.02$ ). Additional factors associated with lactation protein yield included positive relationships with PTA protein concentration and yield, PRVME, LMILK, and DIM when cows left the herd $(P<0.01)$. Previous lactation days open was the only factor with a negative association $(P<0.001)$.

Associations between study group and average LSC throughout lactation was dependent on fresh month, mastitis at first test, and LLSC $(P<0.01)$. The interaction with fresh month showed no clear pattern. Average LSC increased with increasing LLSC for all study groups except $\mathrm{A}_{\mathrm{D}} \mathrm{S}_{\mathrm{G}}$ (Supplemental Figure $\mathrm{S} 5$, https://doi.org/ 10.3168/jds.2020-18462). The positive relationship was greatest for $\mathrm{A}_{\mathrm{D}} \mathrm{L}_{\mathrm{G}}$. We detected no difference in average LSC between study groups in second-lactation cows, but in cows with $3+$ lactations, average LSC was greatest for $A_{D} L_{G}$ cows, least for $A_{D} A_{G}$, and intermediate for other study groups. Overall average LSC was greatest for cows with mastitis at first test (3.26 vs. $2.15 \pm 0.16$ ) and cows with $3+$ lactations (2.61 vs. $2.10 \pm 0.16 ; P$ $<0.001)$. Average LSC decreased with PRVME and LMILK but increased with LLSC $(P \leq 0.01)$.

\section{Reproductive Variables}

Differences for days to first service between study groups were dependent on CFDIF ( $P=0.01$; Table 4). Although no difference was detectable between study groups for cows without CFDIF, hazard of insemination (reduced calving to first service interval) for cows with CFDIF was greatest for $A_{D} A_{G}$ and $S_{D} A_{G}$, least for $A_{D} S_{G}$, and intermediate for others. Overall, median number of days to first service was 67 . Conception risk at first service was not associated with study group $(P=0.06)$. First service conception risk was greatest for cows in their second lactation, that had carried female calves born alive, and varied by fresh month $(P<$ 0.001). Factors positively associated with first service conception risk were MY1 and DIM at first service, whereas LMILK and PDOPN were negatively associated $(P \leq 0.001)$.

Number of days open (up to 365 DIM) was associated with study group; hazard of pregnancy was less for $A_{D} L_{G}$ compared with $A_{D} A_{G}$, but days open did not differ for any other study group compared with $A_{D} A_{G}$ (Table 4). Overall, cows with a calf DOA had poorer fertility $(P<0.001)$; and although no fertility differ- ence was detected between study groups for cows with calves born alive, within cows that had a calf DOA, fertility was greater for $A_{D} A_{G}$ compared with all other study groups $(P=0.02)$. Fertility was less for cows in their third or greater lactation and cows that had twins, and was positively associated with MY1 and negatively associated with PRVME, PDOPN, and fat: protein concentration at first test.

\section{Herd Retention}

Hazard of removal from the herd by either death or culling within in the first 60 DIM differed by study group, was greater for cows in their third or greater parity and those with mastitis at first test, increased with PDOPN, and decreased with increased MY1 $(P \leq 0.04$; Table 5). Results of the multinomial model indicated that hazard of removal was 34 and $30 \%$ greater for $\mathrm{A}_{\mathrm{D}} \mathrm{S}_{\mathrm{G}}$ and $\mathrm{L}_{\mathrm{D}} \mathrm{A}_{\mathrm{G}}$ compared with $\mathrm{A}_{\mathrm{D}} \mathrm{A}_{\mathrm{G}}(P<0.05)$, but no significant difference was detected for $S_{D} S_{G}$ despite being the group with the greatest hazard of removal in the Kaplan-Meier curve (Figure 8A). Because MY1 was least for $\mathrm{S}_{\mathrm{D}} \mathrm{S}_{\mathrm{G}}$, it is probable that the incongruence between the Kaplan-Meier curve and the Cox model is due to a large proportion of the $\mathrm{S}_{\mathrm{D}} \mathrm{S}_{\mathrm{G}}$ effect being explained by the MY1 term in the Cox model.

When analyzed through 365 DIM, herd removal differed by study group, was greater for cows in lactation 3+ and those with mastitis at first test, and was positively related to PDOPN but negatively related to MY1 and LMILK $(P<0.001)$. Similar to the $60-\mathrm{d}$ model, differences for study groups did not align between the multivariate analysis and the Kaplan-Meier graph (Figure 8B). The multivariate model indicated $24 \%$ greater hazard of removal for $\mathrm{L}_{\mathrm{D}} \mathrm{A}_{\mathrm{G}}$ compared with $A_{D} A_{G}$, whereas hazard was similar for all other study groups compared with $\mathrm{A}_{\mathrm{D}} \mathrm{A}_{\mathrm{G}}$. The $33 \%$ greater hazard of removal generated for $S_{D} S_{G}$ in the univariate Cox models is likely explained by other variables included in the multivariate model.

\section{DISCUSSION}

Previous retrospective studies that investigated the associations between DPL and subsequent lactation productivity failed to consider potential reasons for the deviation in DPL (Makuza and McDaniel, 1996; Pinedo et al., 2011; Santschi and Lefebvre, 2014). In those studies, cows with a shortened dry period were likely cows that calved early for various reasons (carrying twins, abortion), many of which are independently associated with poor performance (Bachman and Schairer, 2003; Overton, 2005). Further stratification of DPL by GL 


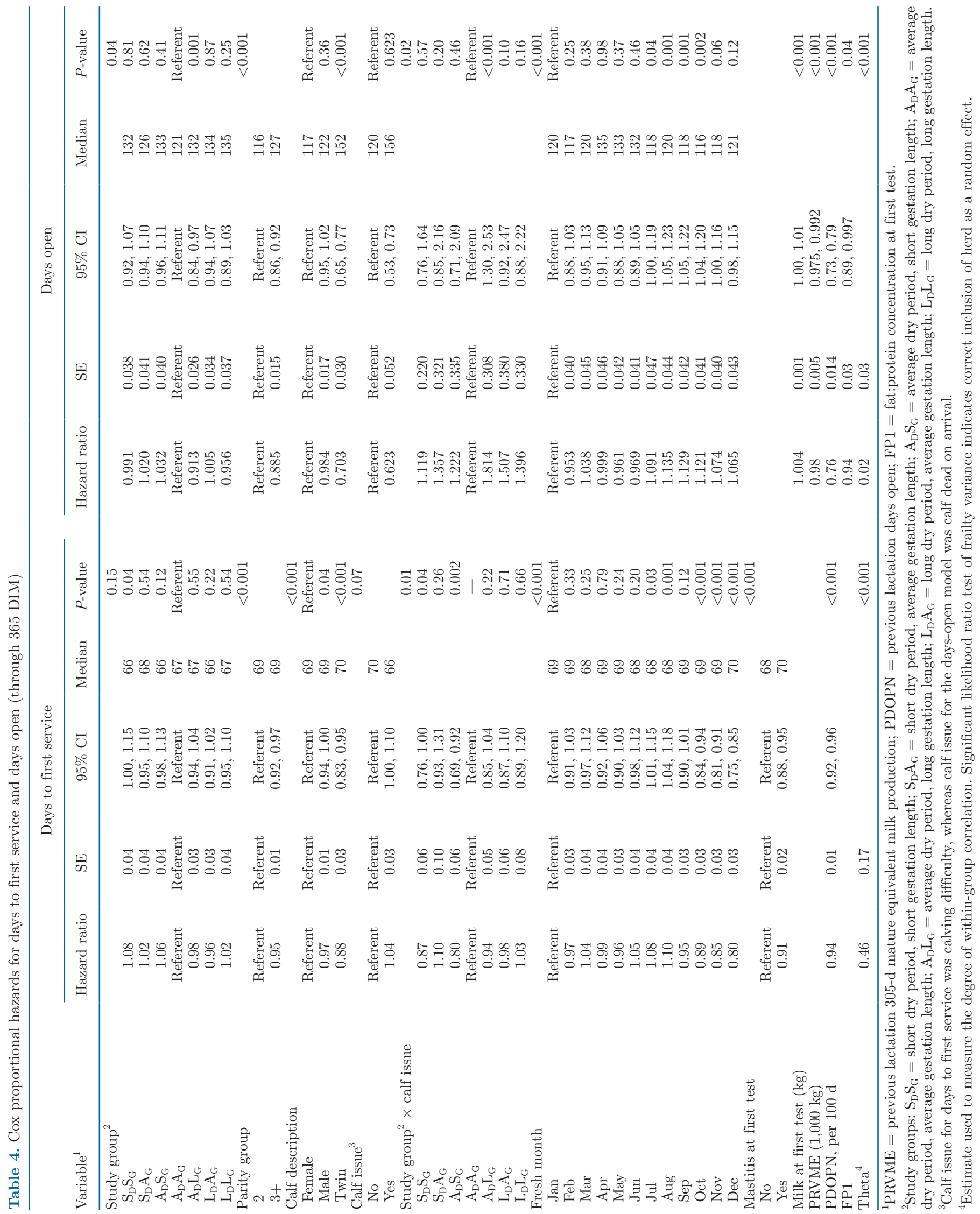


Olagaray et al.: DRY PERIOD LENGTH

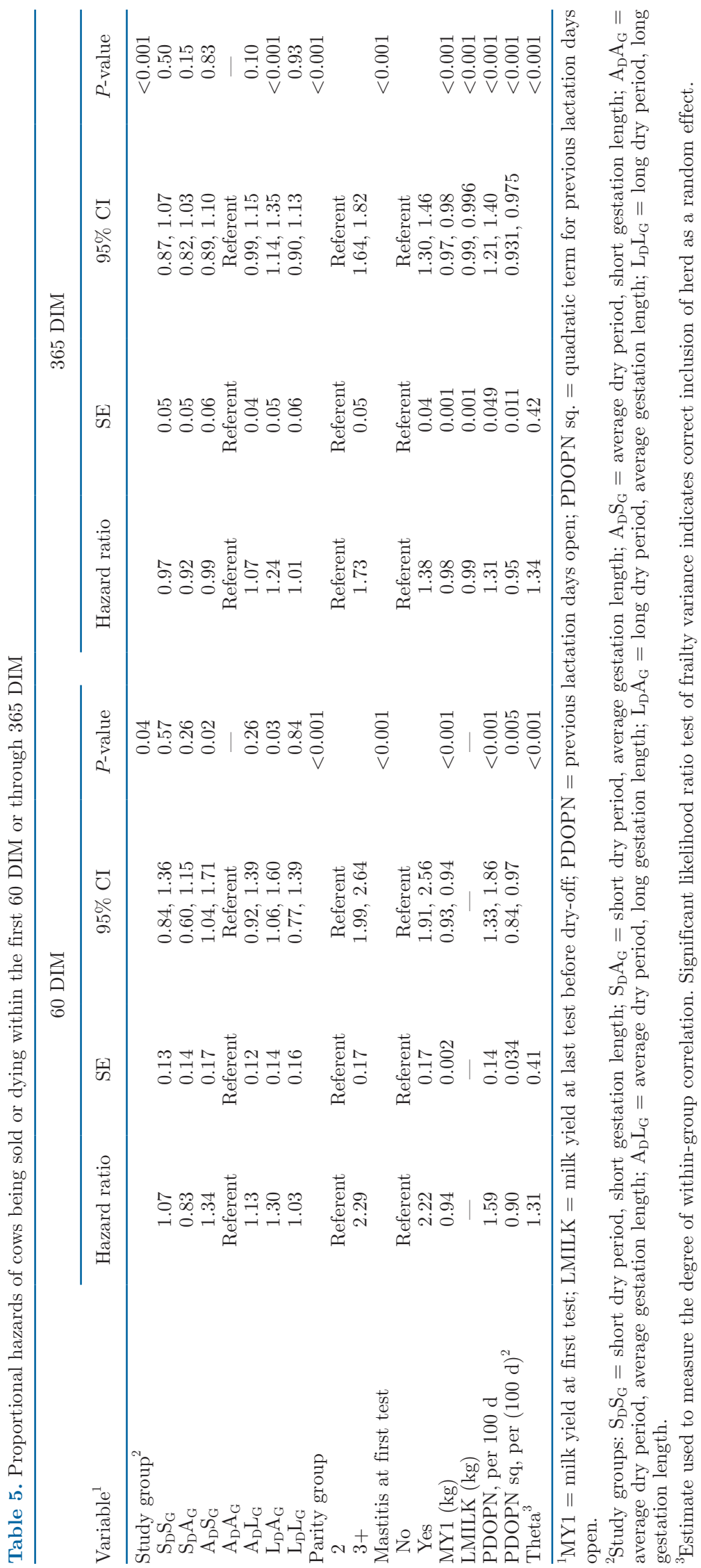


allowed us to begin to tease apart the effects of DPL coupled with involuntary GL deviations from those more directly associated with DPL.

Although the target DPL was $60 \mathrm{~d}$ for all but 1 herd (dairy $\mathrm{I}=55 \mathrm{~d}$ ), considerable variation in DPL distribution occurred across farms (Supplemental Figure S1A, https://doi.org/10.3168/jds.2020-18462). For example, the DPL ranges for the herds with the tightest and widest DPL distribution were 34 to $83 \mathrm{~d}$, compared with 16 to $135 \mathrm{~d}$. The intraclass correlation coefficients obtained from a univariate model for DPL indicated that $14.4 \%$ of the variability in DPL occurred at the herd level. Similarly, GL distributions varied by herd (Supplemental Figure S1B, https://doi.org/10.3168/ jds.2020-18462), although only $2.6 \%$ of the variation was explained by herd. Our objective was to segregate DPL effects caused by biological versus management reasons. Thus, DPL and GL categorization at the farm level was deemed most appropriate to meet our objective, rather than categorizing across the distribution
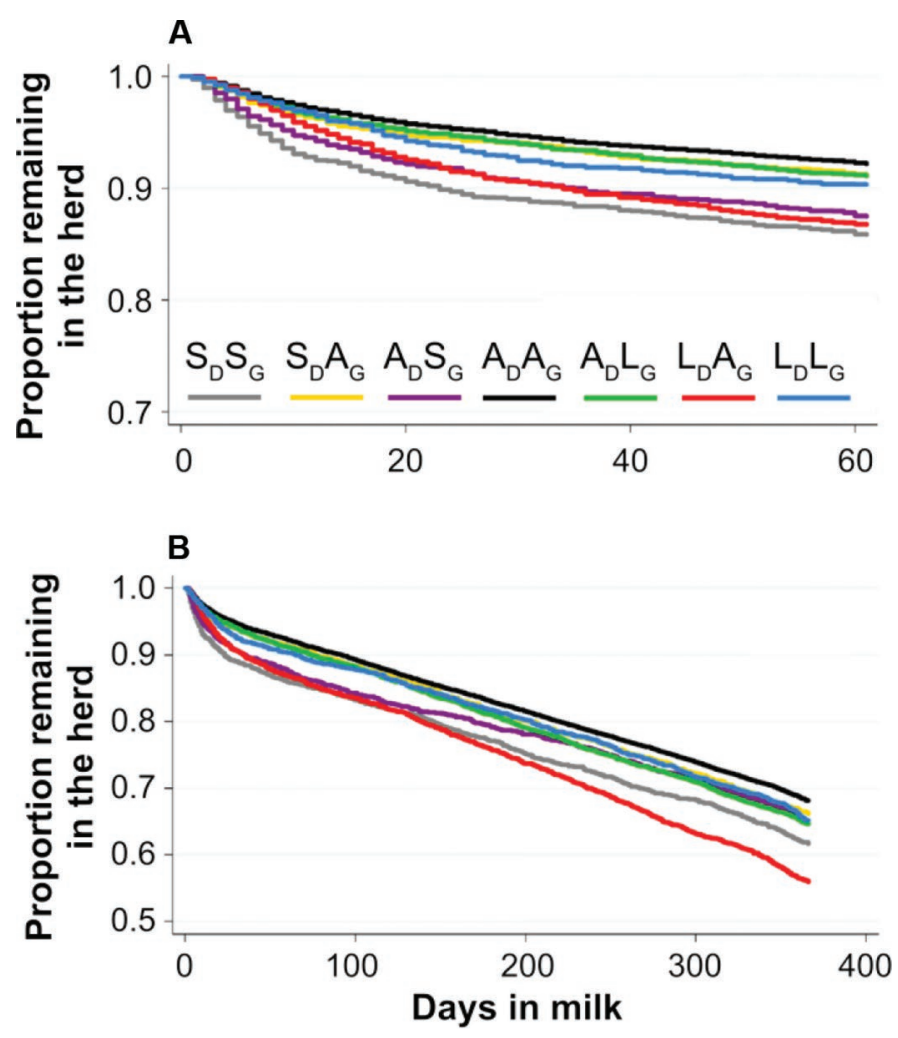

Figure 8. Kaplan-Meier survival curves for time to leave the herd by either death or culling to (A) 60 DIM or (B) 365 DIM. Study groups: $\mathrm{S}_{\mathrm{D}} \mathrm{S}_{\mathrm{G}}=$ short dry period, short gestation length; $\mathrm{S}_{\mathrm{D}} \mathrm{A}_{\mathrm{G}}=$ short dry period, average gestation length; $\mathrm{A}_{\mathrm{D}} \mathrm{S}_{\mathrm{G}}=$ average dry period, short gestation length; $A_{D} A_{G}=$ average dry period, average gestation length; $\mathrm{A}_{\mathrm{D}} \mathrm{L}_{\mathrm{G}}=$ average dry period, long gestation length; $\mathrm{L}_{\mathrm{D}} \mathrm{A}_{\mathrm{G}}=$ long dry period, average gestation length; $\mathrm{L}_{\mathrm{D}} \mathrm{L}_{\mathrm{G}}=$ long dry period, long gestation length. of the entire data set or using predefined thresholds determined by literature.

\section{Long Dry Period Associations}

Coupled with a long or average dry period, little evidence indicated that extended GL hampered subsequent lactation productivity. The interaction of study group with PRVME for MY1 suggested the most positive relationship for $\mathrm{L}_{\mathrm{D}} \mathrm{L}_{\mathrm{G}}$, suggesting that cows with greater lactation potential actually benefited from the longer DPL and GL. Long GL was again associated with the most positive relationship between PRVME and $305 \mathrm{MEq}$ milk in the following lactation, but only for long-gestation cows with average DPL. Little effect of long GL with an average or long DPL is consistent with the lack of effect of long GL on milk yield through 300 DIM reported by Vieira-Neto et al. (2017). The only relationship between long gestation and milk components was less milk protein yield for $\mathrm{L}_{\mathrm{D}} \mathrm{L}_{\mathrm{G}}$ compared with $A_{D} A_{G}$ and $A_{D} L_{G}$.

Adverse associations with long DPL were exhibited in $\mathrm{L}_{\mathrm{D}} \mathrm{A}_{\mathrm{G}}$ cows and closely aligned with the negative consequences of excessive body condition at calving. Extended dry periods increase the odds of BCS gain (Chebel et al., 2018), which, in turn, can lead to enhanced lipolysis and metabolic stress at calving (Weber et al., 2015). This metabolic scenario also generally results in poor DMI postpartum (Schuh et al., 2019), contributing further to metabolic disease and increased risk of culling (Morrow, 1976). Mammary uptake of these mobilized fatty acids subsequently results in greater milk fat concentration and a greater milk fat to protein ratio (de Vries and Veerkamp, 2000). Both milk fat concentration and FP1 were greater for lowproducing $\mathrm{L}_{\mathrm{D}} \mathrm{A}_{\mathrm{G}}$ cows and decreased with greater milk yield more than any other group. The low production coupled with greater milk fat and milk FP1 indicates that a subgroup of $\mathrm{L}_{\mathrm{D}} \mathrm{A}_{\mathrm{G}}$ struggled. Additionally, both milk fat concentration and FP1 had strong positive relationships with PDOPN, which provides more support for the focus on overconditioning, as this is a greater risk for cows conceiving later in lactation (De Vries et al., 2010). On the other hand, despite being challenged with excessive lipid mobilization, likely due to excessive body condition, $\mathrm{L}_{\mathrm{D}} \mathrm{A}_{\mathrm{G}}$ cows with greater initial levels of production showed fat:protein ratios in early lactation (FP1) similar to those of cows in other study groups. Although our study was not designed to parse out reasons for different responses to such challenges, risk factors such as dystocia would be expected to decrease peripartum feed intake (Proudfoot et al., 2009). Cows with adequate feed intake postpartum are better able to keep the rate of lipolysis moderate and are also able 
to increase milk production more quickly (Ingvartsen, 2006). Whatever the underlying causes, we speculate that $\mathrm{L}_{\mathrm{D}} \mathrm{A}_{\mathrm{G}}$ cows with greater initial milk production benefited from greater postpartum DMI.

Despite potential challenges with lipid metabolism in early lactation, neither first test milk yield nor 305-d MEq milk yield were different for $\mathrm{L}_{\mathrm{D}} \mathrm{A}_{\mathrm{G}}$ cows compared with $\mathrm{A}_{\mathrm{D}} \mathrm{A}_{\mathrm{G}}$. The likely metabolic issues did, however, manifest in 30 and $24 \%$ greater risks of death or culling by 60 and 365 DIM, respectively, compared with $A_{D} A_{G}$. Previous studies have associated greater early-lactation fat:protein ratio with greater odds of postpartum disease (retained placenta, displaced abomasum, and metritis) and increased risk of culling, especially within the first $30 \mathrm{~d}$ of lactation (Toni et al., 2011). Heuer et al. (1999) reported that even though milk production was greater, cows with FP ratio $>1.5$ had greater risk of disease and poorer reproductive performance (decreased first service conception risk, increased calving-to-conception interval, and increased services per conception). Despite indications of metabolic stress and the greater odds of removal from the herd, reproductive variables were not different for $\mathrm{L}_{\mathrm{D}} \mathrm{A}_{\mathrm{G}}$ cows. The greater earlylactation cull rate likely removed cows that would have had poor reproductive performance, had they remained in the herd longer and been subjected to reproductive protocols.

\section{Short Dry Period Associations}

In general, subsequent lactation performance was the worst for cows with both a short DPL and a short GL. Both early-lactation and whole-lactation milk and component yields were least for $S_{D} S_{G}$ compared with other groups. Comparisons of $\mathrm{S}_{D} \mathrm{~S}_{G}$ with $\mathrm{S}_{\mathrm{D}} \mathrm{A}_{\mathrm{G}}$ and $\mathrm{A}_{\mathrm{D}} \mathrm{S}_{\mathrm{G}}$ suggest that GL is likely a larger contributor to poor performance than short DPL is. The $\mathrm{A}_{\mathrm{D}} \mathrm{S}_{\mathrm{G}}$ study group was also associated with lesser MY1, and milk fat and protein yield at first test were intermediate between $\mathrm{S}_{\mathrm{D}} \mathrm{S}_{\mathrm{G}}$ and $\mathrm{A}_{\mathrm{D}} \mathrm{A}_{\mathrm{G}}$. Unlike $\mathrm{S}_{\mathrm{D}} \mathrm{S}_{\mathrm{G}}$, impaired performance did not completely extend throughout lactation among $\mathrm{A}_{\mathrm{D}} \mathrm{S}_{\mathrm{G}}$ cows, as $305 \mathrm{MEq}$ was similar to that of other study groups; however, differences in milk fat yield did continue, with whole-lactation yield of $\mathrm{A}_{\mathrm{D}} \mathrm{S}_{\mathrm{G}}$ cows intermediate to those of $\mathrm{S}_{\mathrm{D}} \mathrm{S}_{\mathrm{G}}$ and $\mathrm{A}_{\mathrm{D}} \mathrm{A}_{\mathrm{G}}$. Kaplan-Meier survival graphs illustrated greater removal from the herd within the first $60 \mathrm{~d}$ of lactation for both $\mathrm{S}_{\mathrm{D}} \mathrm{S}_{\mathrm{G}}$ and $A_{D} S_{G}$ relative to both $A_{D} A_{G}$ and $S_{D} A_{G}$. After adjusting for parity group, mastitis at first test, milk at first test, LMILK, and PDOPN, hazard of removal was $34 \%$ greater for $A_{D} S_{G}$ but only $7 \%$ greater for $S_{D} S_{G}$ (both relative to $A_{D} A_{G}$ ). Because MY1 was positively associated with survival and MY1 was less for $S_{D} S_{G}$, a large proportion of variance that would've been explained by the $\mathrm{S}_{\mathrm{D}} \mathrm{S}_{\mathrm{G}}$ study group was likely captured by the MY1 variable. Days to first service were also greater for both $S_{D} S_{G}$ and $A_{D} S_{G}$ cows that had CFDIF. The main difference between $S_{D} A_{G}$ and $A_{D} A_{G}$ was greater LSC1 for $\mathrm{S}_{\mathrm{D}} \mathrm{A}_{\mathrm{G}}$. Thus, our data set suggests that despite some negative effects of a short dry period, the parallels between $\mathrm{S}_{D} \mathrm{~S}_{\mathrm{G}}$ and $\mathrm{A}_{\mathrm{D}} \mathrm{S}_{\mathrm{G}}$ point to short GL as a greater contributor to poor performance, which can be further compounded by a short DPL.

The performance parallels between $\mathrm{S}_{\mathrm{D}} \mathrm{S}_{\mathrm{G}}$ and $\mathrm{A}_{\mathrm{D}} \mathrm{S}_{\mathrm{G}}$ seem to support our hypothesis that dry periods at least in part caused by shorter GL result in poorer performance. As noted previously, the poor performance associations with short DPL in past retrospective studies were likely because of factors that stimulated early calving and thus resulted in the involuntary short DPL (Bachman and Schairer, 2003; Overton, 2005). Known factors associated with reduced GL, carrying twins, female versus male calves, heifers versus cows (Norman et al., 2009, also found in this data set), and dry period heat stress (Tao et al., 2012), are also associated with lower production and increased perinatal morbidity (Tao et al., 2012; Damaso et al., 2018). Even after controlling for GL, parity, season of calving, and sex of calves, Vieira-Neto et al. (2017) reported that short GL $($ mean $=266$, range $=256-269)$ was associated with greater incidences of stillbirth, retained placenta, and metritis, higher rate of removal from the herd (38\% greater through 300 DIM), decreased milk yield, and smaller proportion of cows receiving at least $1 \mathrm{AI}$. Therefore, short GL seems to be the primary culprit for poor performance that had previously been attributed to short dry periods. We do not imply that short GL is necessarily causal for impaired health and productivity; rather, we speculate that early parturition is commonly a response to physiological stressors that (in addition to triggering early parturition) also lead to impaired health and milk secretion. One established example is heat stress; failing to adequately cool late-gestation cows in a hot, humid environment shortened gestation by $4 \mathrm{~d}$, on average (Tao et al., 2012), while also decreasing subsequent productivity (Dahl et al., 2017). Other problems, perhaps with the common characteristic of driving peripartum inflammation (Bradford et al., 2015), could trigger early parturition, although this has been better studied in humans than in cattle (Wei et al., 2010).

The lack of differences for lactation variables, survival, and reproduction between $\mathrm{S}_{\mathrm{D}} \mathrm{A}_{\mathrm{G}}$ and $\mathrm{A}_{\mathrm{D}} \mathrm{A}_{\mathrm{G}}$ cows aligns with suggestions that a shorter dry period may be better for the modern high-producing dairy cow (Kuhn et al., 2005). Several controlled studies comparing short DPL (30-35 d) with traditional DPL (55-60 d) showed either no difference in subsequent milk yield 
(Bachman, 2002; Gulay et al., 2003; Rastani et al., 2005) or milk yield decreases that were restricted to second-lactation cows (Annen et al., 2004b; Watters et al., 2009; Pezeshki et al., 2010; Santschi et al., 2011).

At first glance, the main effects for $\mathrm{S}_{\mathrm{D}} \mathrm{A}_{\mathrm{G}}$ in our study support the idea that short dry periods may be appropriate for today's high-yielding dairy cows. However, Kok et al. (2017) used thousands of lactations across 16 herds to conclude that a 6 - to 8-wk dry period supported the greatest whole-lactation fat and protein yield, further justifying the standard practice for most farms. Our observed interactions also support the caution of Santschi and Lefebvre (2014) that short dry periods may not be suitable for all cows or herds. Milk yield at last test before dry-off was negatively associated with MY1 for $S_{D} A_{G}$ cows, and LSC1 was greater for $S_{D} A_{G}$ across all levels of LLSC. These results align with the findings from a controlled experiment, where eliminating the dry period increased subsequent mastitis risk among cows with high SCC in late lactation (van Hoeij et al., 2016). Although milk yield has increased by 30 to $40 \%$ in the last 4 decades (Thornton, 2010), sudden dry-off is still the most common management practice on commercial dairy farms (Bertulat et al., 2015). Milk yield at last test before dry-off (restricted to within $40 \mathrm{~d}$ of dry-off) ranged from 0.9 to $78.5 \mathrm{~kg}$ (median = 28.1 , interquartile range $=21.8-34.5 \mathrm{~kg}$ ). Greater milk yield at dry-off is associated with greater prevalence of milk leakage and slower formation of the keratin plug, which leaves the teat canal open for bacterial entry, increasing susceptibility to IMI (Rovai et al., 2007). The negative interaction between length of previous lactation (PDOPN) and MY1 suggests that $\mathrm{S}_{\mathrm{D}} \mathrm{A}_{\mathrm{G}}$ cows would benefit from earlier dry-off. Although it is common practice to extend lactations for high-producing cows, our evidence suggests that this practice hinders performance. Thus, our data support Dingwell et al. (2002), in that cows with high levels of production at dry-off should not be subjected to a short dry period. Other strategies can be used to reduce milk yield before dry-off, including intermittent milking and low-energy rations (Dingwell et al., 2001).

Cows with the greatest genetic potential seemed to be most sensitive to short GL and DPL. The positive relationship between PRVME and MY1 was weakest for $S_{D} S_{G}$ cows and intermediate for $S_{D} A_{G}$ and $A_{D} S_{G}$, compared with cows with combinations of average or long DPL and GL. The study group interaction for first test protein yield and PRVME indicated lower milk protein yield for the groups with worst early-lactation survival $\left(\mathrm{S}_{\mathrm{D}} \mathrm{S}_{\mathrm{G}}, \mathrm{A}_{\mathrm{D}} \mathrm{S}_{\mathrm{G}}\right.$, and $\left.\mathrm{L}_{\mathrm{D}} \mathrm{A}_{\mathrm{G}}\right)$ as PRVME increased. Predicted 305-d MEq milk yield and whole-lactation fat yield increased with increasing PRVME, but to the lowest degree for $S_{D} S_{G}$ and $A_{D} S_{G}$. Thus, cows with the greatest milking potential, based on PRVME, were most negatively affected by short gestation.

Our data do support previous studies suggesting that shortened dry periods (approximately $40 \mathrm{~d}$ ) may be an option for today's high-producing dairy cows; however, cow production potential, calving interval, and milk yield at dry-off should all be considered when making such a decision. When making decisions related to DPL, it should be realized that natural variation in actual versus expected calving date and the normal distribution of GL present within every farm will inevitably result in cows having shorter or longer DPL than managed for (Overton, 2005).

\section{Has Gestation Length Shortened?}

A 280-d gestation has been the hallmark for Holstein dairy cows and is used in most herd management software, unless manually adjusted, to determine expected calving date. Such is supported by Norman et al. (2009) with their data set of 11 million parturitions from 1999 to 2006 that generated GL means of 277.8 and $279.4 \mathrm{~d}$ for Holstein heifers and cows, respectively. More recently, Vieira-Neto et al. (2017) reported a GL mean and SD of $276 \pm 6 \mathrm{~d}$ from their data set of primiparous and multiparous cows from 2 California herds. In our data, GL mean and SD of $277 \pm 5 \mathrm{~d}$ was slightly greater, as it only included multiparous cows, but supports their findings and, together, suggest that GL for Holstein cows may be decreasing. It is important to note that our data set and that of Vieira-Neto et al. (2017) have been cleaned and exclude extreme GL (shorter or longer than $3 \mathrm{SD}$ from the mean) that may otherwise inflate or deflate a raw herd average. In further support, the 5 million Holstein bulls (born after 1995) used to develop the PTA for GL reported a base GL of $277 \mathrm{~d}$ and SD of $1.4 \mathrm{~d}$ (Wright and VanRaden, 2017).

\section{Study Limitations}

Farms included in this study represent a convenience sample of dairy farms in the Western and Midwestern United States. Thus, some selection bias is present, as the farms do not represent a random sample of farms from our target population (large commercial dairy farms in the United States). Inclusion of more herds, especially herds from the Eastern US, would have increased our external validity while also allowing for investigation of regional and herd-level effects.

Further stratification of DPL by GL was employed as a means to segregate DPL categories into either biological or management reasons for the deviation. Biological reasons for a short or long GL could be attributed to stressors (such as social or environmental 
stresses, and others) and genetics. Although reasons for management-related DPL deviations cannot be specifically be determined in our study, possibilities could include postponed dry-off due to pen space limitations and high levels of milk production at time of dry-off, among others. One notable limitation related to our classification of cows relates to improper recording of conception dates. Such would be considered a management issue; however, as we could not definitively determine which cows this might have affected, they likely were classified into the study groups representing biological reasons $\left(\mathrm{S}_{\mathrm{D}} \mathrm{S}_{\mathrm{G}}\right.$ or $\left.\mathrm{L}_{\mathrm{D}} \mathrm{L}_{\mathrm{G}}\right)$.

To account for seasonality, month of calving was included in all our models. We considered further categorization by season but felt it might be misleading for our data set, given the differences in climates across herds. Although differences in weather characteristics are also present when comparing months across region, we believed its inclusion would best account for seasonality while also decreasing risk for misinterpretation. If our data set allowed, a variable categorized by temperature and humidity index or the ability to account for region would have strengthened the interpretative ability of seasonality in our models.

Many explanatory variables were included in the models, to account for potential biases across study groups; however, we have identified additional variables that should be accounted for in the future. Stocking density of dry pens could greatly influence both management decisions regarding timing of dry-off and biological stress on the animal that could contribute to early calving. A metric related to stocking density would be helpful to account for such variation across study groups, as well as to account for its direct effect on cow performance in the subsequent lactation. The bias of milk production potential across groups is somewhat accounted for by the inclusion of PRVME in models; however, reproductive protocols (e.g., use of sexed semen) also vary by production potential but were not accounted for in our study. A variable for sexed versus conventional semen could be implemented when evaluating reproductive efficiency across groups, so that the decreased reproductive efficiency associated with sexed semen is not unintentionally attributed to the study group. Inclusion of these variables would further strengthen future models.

\section{CONCLUSIONS}

Retrospective observational studies investigating effects of DPL need to account for causes underlying the deviations in DPL. In stratifying DPL by GL, we determined short GL to be the main factor associated with poor performance in the subsequent lactation. Short dry period did appear to compound the effects of short GL, as lactation performance and herd retention rate were least for $\mathrm{S}_{\mathrm{D}} \mathrm{S}_{\mathrm{G}}$ cows compared with any other study group. Overall productivity was similar between $S_{D} A_{G}$ and $A_{D} A_{G}$, which supports the use of shorter dry periods (approximately $40 \mathrm{~d}$ ); however, based on interactions with PRVME and LMILK, a short dry period should not be applied to cows with high production potential or high milk production at dry-off. Long GL, independent of DPL, had little effect on subsequent lactation performance. Greater milk fat concentration and FP1 in cows subjected to a long dry period due to management decisions $\left(\mathrm{L}_{\mathrm{D}} \mathrm{A}_{\mathrm{G}}\right)$ indicated issues with earlylactation lipid metabolism that ultimately resulted in decreased herd retention. In conclusion, deviations in DPL caused by biology have greater influence relating to short DPL, whereas management reasons for DPL deviation have the greatest effect in causing long dry periods.

\section{ACKNOWLEDGMENTS}

First, this study would not have been possible without the participation of several nutritionists and dairy owners and managers, and we thank them for their willingness to share data and answer our many questions. The authors thank Luís Mendonça (Department of Animal Sciences and Industry, Kansas State University, Manhattan, KS) for his assistance with Dairy Comp 305 and Natalia Cernicchiaro (Diagnostic Medicine/ Pathobiology, College of Veterinary Medicine, Kansas State University) for her guidance and troubleshooting with the statistical analysis. The authors have not stated any conflicts of interest.

\section{REFERENCES}

Annen, E. L., R. J. Collier, M. A. Mcguire, and J. L. Vicini. 2004a. Effects of dry period length on milk yield and mammary epithelial cells. J. Dairy Sci. 87:E66-E76. https://doi.org/10.3168/jds.S0022 -0302(04)70062-4.

Annen, E. L., R. J. Collier, M. A. Mcguire, J. L. Vicini, J. M. Ballam, and M. J. Lormore. 2004b. Effect of modified dry period lengths and bovine somatotropin on yield and composition of milk from dairy cows. J. Dairy Sci. 87:3746-3761. https://doi.org/10.3168/ jds.S0022-0302(04)73513-4.

Arnold, P. T., and R. B. Becker. 1936. Influence of preceding dry period and of mineral supplementation on lactation. J. Dairy Sci 19:257-266. https://doi.org/10.3168/jds.S0022-0302(36)93061-8.

Atashi, H., M. J. Zamiri, and M. Dadpasand. 2013. Association between dry period length and lactation performance, lactation curve, calf birth weight, and dystocia in Holstein dairy cows in Iran. J. Dairy Sci. 96:3632-3638. https://doi.org/10.3168/jds.2012 $-5943$.

Bachman, K. C. 2002. Milk production of dairy cows treated with estrogen at the onset of a short dry period. J. Dairy Sci. 85:797-803. https://doi.org/10.3168/jds.S0022-0302(02)74138-6. 
Bachman, K. C., and M. L. Schairer. 2003. Bovine studies on optimal lengths of dry periods. J. Dairy Sci. 86:3027-3037. https://doi.org/ 10.3168/jds.S0022-0302(03)73902-2.

Bertulat, S., C. Fischer-Tenhagen, and W. Heuwieser. 2015. A survey of drying-off practices on commercial dairy farms in northern Germany and a comparison to science-based recommendations. Vet. Rec. Open 2:e000068. https://doi.org/10.1136/vetreco-2014 -000068 .

Bradford, B. J., K. Yuan, J. K. Farney, L. K. Mamedova, and A. J. Carpenter. 2015. Inflammation during the transition to lactation: New adventures with an old flame. J. Dairy Sci. 98:6631-6650.

Chebel, R. C., L. G. D. Mendonça, and P. S. Baruselli. 2018. Association between body condition score change during the dry period and postpartum health and performance. J. Dairy Sci. 101:45954614. https://doi.org/10.3168/jds.2017-13732.

Dahl, G. E., S. Tao, and J. Laporta. 2017. Triennial Lactation Symposium/BOLFA: Late gestation heat stress of dairy cattle programs dam and daughter milk production. J. Anim. Sci. 95:5701-5710. https://doi.org/10.2527/jas2017.2006.

Damaso, A. F., M. Velasova, S. Van Winden, Y. Chang, and J. Guitian. 2018. Occurrence of preterm calving in Great Britain and associations with milk production and reproductive performance in dairy cattle. Vet. Rec. Open. 5:e000221. https://doi.org/10.1136/ vetreco-2017-000221.

De Vries, A., J. D. Olson, and P. J. Pinedo. 2010. Reproductive risk factors for culling and productive life in large dairy herds in the eastern United States between 2001 and 2006. J. Dairy Sci. 93:613-623. https://doi.org/10.3168/jds.2009-2573.

de Vries, M. J., and R. F. Veerkamp. 2000. Energy balance of dairy cattle in relation to milk production variables and fertility. J. Dairy Sci. 83:62-69. https://doi.org/10.3168/jds.S0022-0302(00)74856-9.

Dingwell, R. T., T. F. Duffield, K. E. Leslie, G. P. Keefe, L. Descoteaux, D. F. Kelton, K. D. Lissemore, Y. H. Schukken, P. Dick, and R. Bagg. 2002. The efficacy of intramammary tilmicosin at dryingoff, and other risk factors for the prevention of new intramammary infections during the dry period. J. Dairy Sci. 85:3250-3259. https: //doi.org/10.3168/jds.S0022-0302(02)74413-5.

Dingwell, R. T., D. F. Kelton, K. E. Leslie, and V. L. Edge. 2001. Deciding to dry-off: Does level of production matter? Pages 69-79 in Proc. National Mastitis Council Annual Meeting, Reno, NV. Natl. Mastitis Counc. Inc., Madison, WI.

Funk, D. A., A. E. Freeman, and P. J. Berger. 1987. Effects of previous days open, previous days dry, and present days open on lactation yield. J. Dairy Sci. 70:2366-2373. https://doi.org/10.3168/jds .S0022-0302(87)80297-7.

Gädicke, P., and G. Monti. 2013. Factors related to the level of occurrence of bovine abortion in Chilean dairy herds. Prev. Vet. Med. 110:183-189. https://doi.org/10.1016/j.prevetmed.2012.11.022.

Gulay, M. S., M. J. Hayen, K. C. Bachman, T. Belloso, M. Liboni, and H. H. Head. 2003. Milk production and feed intake of Holstein cows given short (30-d) or normal (60-d) dry periods. J. Dairy Sci. 86:2030-2038. https://doi.org/10.3168/jds.S0022-0302(03)73792 -8 .

Heuer, C., Y. H. Schukken, and P. Dobbelaar. 1999. Postpartum body condition score and results from the first test day milk as predictors of disease, fertility, yield, and culling in commercial dairy herds. J. Dairy Sci. 82:295-304. https://doi.org/10.3168/jds.S0022 -0302(99)75236-7.

Ingvartsen, K. L. 2006. Feeding- and management-related diseases in the transition cow: Physiological adaptations around calving and strategies to reduce feeding-related diseases. Anim. Feed Sci. Technol. 126:175-213.

Keown, J. F., and R. W. Everett. 1986. Effect of days carried calf, days dry, and weight of first calf heifers on yield. J. Dairy Sci. 69:18911896. https://doi.org/10.3168/jds.S0022-0302(86)80615-4.

Kok, A., A. T. M. van Knegsel, C. E. van Middelaar, B. Engel, H. Hogeveen, B. Kemp, and I. J. M. de Boer. 2017. Effect of dry period length on milk yield over multiple lactations. J. Dairy Sci. 100:739-749. https://doi.org/10.3168/jds.2016-10963.
Kuhn, M. T., J. L. Hutchison, and H. D. Norman. 2005. Minimum days dry to maximize milk yield in subsequent lactation. Anim. Res. 54:351-367. https://doi.org/10.1051/animres:2005031.

Makuza, S. M., and B. T. McDaniel. 1996. Effects of days dry, previous days open, and current days open on milk yields of cows in Zimbabwe and North Carolina. J. Dairy Sci. 79:702-709. https:// doi.org/10.3168/jds.S0022-0302(96)76416-0.

Morrow, D. A. 1976. Fat cow syndrome. J. Dairy Sci. 59:1625-1629. https://doi.org/10.3168/jds.S0022-0302(76)84415-3.

Norman, H. D., J. R. Wright, M. T. Kuhn, S. M. Hubbard, J. B. Cole, and P. M. Vanraden. 2009. Genetic and environmental factors that affect gestation length in dairy cattle. J. Dairy Sci. 92:2259-2269. https://doi.org/10.3168/jds.2007-0982.

Overton, T. R. 2005. Is there a place for short dry periods for high producing herds? Adv. Dairy Technol. 17:25-34.

Pezeshki, A., A. V. Capuco, B. De Spiegeleer, L. Peelman, M. Stevens, R. J. Collier, and C. Burvenich. 2010. An integrated view on how the management of the dry period length of lactating cows could affect mammary biology and defence. J. Anim. Physiol. Anim. Nutr. (Berl.) 94:e7-e30. https://doi.org/10.1111/j.1439-0396.2010 .00991.x.

Pinedo, P., C. Risco, and P. Melendez. 2011. A retrospective study on the association between different lengths of the dry period and subclinical mastitis, milk yield, reproductive performance, and culling in Chilean dairy cows. J. Dairy Sci. 94:106-115. https:// doi.org/10.3168/jds.2010-3141.

Proudfoot, K. L., J. M. Huzzey, and M. A. G. von Keyserlingk. 2009. The effect of dystocia on the dry matter intake and behavior of Holstein cows. J. Dairy Sci. 92:4937-4944. https://doi.org/10 $.3168 /$ jds.2009-2135.

Rastani, R. R., R. R. Grummer, S. J. Bertics, A. Gümen, and M. C. Wiltbank. 2005. Reducing dry period length to simply feeding transition cows: Milk production, energy balance, and metabolic profiles. J. Dairy Sci. 88:1004-1014. https://doi.org/10.3168/jds .S0022-0302(05)72768-5.

Rovai, M., M. T. Kollmann, and R. M. Bruckmaier. 2007. Incontinentia lactis: Physiology and anatomy conducive to milk leakage in dairy cows. J. Dairy Sci. 90:682-690. https://doi.org/10.3168/jds .S0022-0302(07)71551-5.

Santschi, D. E., and D. M. Lefebvre. 2014. Practical concepts on short dry period management. Can. J. Anim. Sci. 94:381-390. https:// doi.org/10.4141/cjas2013-194.

Santschi, D. E., D. M. Lefebvre, R. I. Cue, C. L. Girard, and D. Pellerin. 2011. Complete-lactation milk and component yields following a short (35-d) or a conventional (60-d) dry period management strategy in commercial Holstein herds. J. Dairy Sci. 94:2302-2311. https://doi.org/10.3168/jds.2010-3594.

Schaeffer, L. R., and C. R. Henderson. 1972. Effects of days dry and days open on Holstein milk production. J. Dairy Sci. 55:107-112. https://doi.org/10.3168/jds.S0022-0302(72)85439-0.

Schuh, K., H. Sadri, S. Häussler, L.A. Webb, C. Urh, M. Wagner, C. Koch, J. Frahm, S. Dänicke, G. Dusel, and H. Sauerwein. 2019. Comparison of performance and metabolism from late pregnancy to early lactation in dairy cows with elevated v. normal body condition at dry-off. Animal 13:1478-1488. https://doi.org/10.1017/ S1751731118003385.

Shook, G. E. 1993. Genetic improvement of mastitis through selection on somatic cell count. Vet. Clin. North Am. Food Anim. Pract. 9:563-581. https://doi.org/10.1016/S0749-0720(15)30622-8.

Tao, S., A. P. A. Monteiro, I. M. Thompson, M. J. Hayen, and G. E. Dahl. 2012. Effect of late-gestation maternal heat stress on growth and immune function of dairy calves. J. Dairy Sci. 95:7128-7136. https://doi.org/10.3168/jds.2012-5697.

Thornton, P. K. 2010. Livestock production: Recent trends, future prospects. Philos. Trans. R. Soc. Lond., B, Biol. Sci. 365:28532867. https://doi.org/10.1098/rstb.2010.0134.

Toni, F., L. Vincenti, L. Grigoletto, A. Ricci, and Y. H. Schukken. 2011. Early lactation ratio of fat and protein percentage in milk is associated with health, milk production, and survival. J. Dairy Sci. 94:1772-1783. https://doi.org/10.3168/jds.2010-3389. 
van Hoeij, R. J., T. J. G. M. Lam, D. B. de Koning, W. Steeneveld, B. Kemp, and A. T. M. van Knegsel. 2016. Cow characteristics and their association with udder health after different dry period lengths. J. Dairy Sci. 99:8330-8340. https://doi.org/10.3168/jds .2016-10901.

van Kengsel, A. T. M, S. G. A. van der Drift, and J. Germakova., and Bas Kemp. 2013. Effects of shortening the dry period of dairy cows on milk production, energy balance, health, and fertility: A systematic review. Vet. J. 198:707-713.

Vieira-Neto, A., K. N. Galvão, W. W. Thatcher, and J. E. P. Santos. 2017. Association among gestation length and health, production, and reproduction in Holstein cows and implications for their offspring. J. Dairy Sci. 100:3166-3181. https://doi.org/10.3168/jds 2016-11867.

Watters, R. D., M. C. Wiltbank, J. N. Guenther, A. E. Brickner, R. R. Rastani, P. M. Fricke, and R. R. Grummer. 2009. Effect of dry period length on reproduction during the subsequent lactation. J. Dairy Sci. 92:3081-3090. https://doi.org/10.3168/jds.2008-1294.

Weber, C., B. Losand, A. Tuchscherer, F. Rehbock, E. Blum, W. Yang, R. M. Bruckmaier, P. Sanftleben, and H. M. Hammon. 2015. Effects of dry period length on milk production, body condition, metabolites, and hepatic glucose metabolism in dairy cows. J. Dairy Sci. 98:1772-1785. https://doi.org/10.3168/jds.2014-8598.
Wei, S.-Q., W. Fraser, and Z.-C. Luo. 2010. Inflammatory cytokines and spontaneous preterm birth in asymptomatic women: A systematic review. Obstet. Gynecol. 116:393-401. https://doi.org/10 .1097/AOG.0b013e3181e6dbc0.

Wiggans, G. R., P. M. Vanraden, J. Bormann, J. C. Philpot, T. Druet, and N. Gengler. 2002. Deriving lactation yields from test-day yields adjusted for lactation stage, age, pregnancy, and herd test date. J. Dairy Sci. 85:264.e1-264.e11. https://doi.org/10.3168/jds .S0022-0302(02)74077-0.

Wright, J.R., and P.M. VanRaden. 2017. Genetic evaluation of gestation length as a trait of the service sire. J. Dairy Sci. 100(Suppl. 2):M100. (Abstr.)

Zobel, G., D. M. Weary, K. E. Leslie, and M. A. G. von Keyserlingk. 2015. Cessation of lactation: Effects on animal welfare. J. Dairy Sci. 98:8263-8277. https://doi.org/10.3168/jds.2015-9617.

\section{ORCIDS}

K. E. Olagaray @ https://orcid.org/0000-0003-2118-7567

M. W. Overton (๑ https://orcid.org/0000-0002-5168-6319

B. J. Bradford ๑ https://orcid.org/0000-0002-6775-4961 